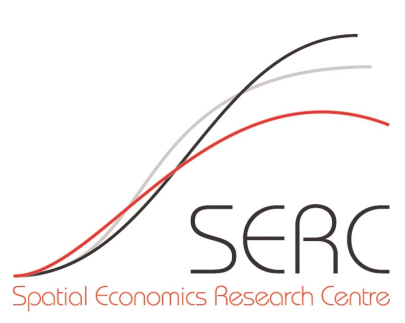

SERC DISCUSSION PAPER 49

\title{
Housing Markets and the Financial Crisis of 2007-2009: Lessons for the
} Future

John V. Duca (Federal Reserve Bank of Dallas, Southern Methodist University, Dallas)

John Muellbauer (SERC, Nuffield College, Oxford University)

Anthony Murphy (Hertford College, Oxford University)

April 2010 
This work was part of the research programme of the independent UK Spatial Economics Research Centre funded by the Economic and Social Research Council (ESRC), Department for Business, Enterprise and Regulatory Reform (BERR), the Department for Communities and Local Government (CLG), and the Welsh Assembly Government. The support of the funders is acknowledged. The views expressed are those of the authors and do not represent the views of the funders.

(C) J. V. Duca, J. Muellbauer and A. Murphy, submitted 2010 


\title{
Housing Markets and the Financial Crisis of 2007-2009: \\ Lessons for the Future
}

\author{
John V. Duca*, John Muellbauer ${ }^{* *}$ \\ and Anthony Murphy
}

April 2010

* Federal Reserve Bank of Dallas, Southern Methodist University, Dallas

** SERC, Nuffield College, Oxford University

*** SERC, Hertford College, Oxford University

Acknowledgements

For comments and suggestions, we thank two anonymous referees, Olympia Bover, Danielle DiMartino, Anil Kumar, Enrique Martinez-Garcia, and participants at the SUERF-Bank of Finland 2009 conference: "Housing Markets: A Shelter From the Storm or a Cause of the Storm?” We also thank Niki Maas and Jessica Renier for research support. The views expressed are those of the authors and do not necessarily reflect those of the Federal Reserve Bank of Dallas, the Board of Governors of the Federal Reserve System or the Bank of Finland. Any remaining errors are our own. John Muellbauer and Anthony Murphy acknowledge support from the UK Economic and Social Research Council via the Spatial Economics Research Centre. 


\begin{abstract}
$\underline{\text { Abstract }}$
An unsustainable weakening of credit standards induced a US mortgage and housing bubble whose consumption impact was amplified by innovations altering the collateral role of housing. In countries with more stable credit standards, any overshooting of construction and house prices owed more to traditional housing supply and demand factors. Housing collateral effects on consumption varied, depending on the liquidity of housing wealth. Lessons include recognizing the importance of financial innovation, regulation, housing policies, and global financial imbalances for fueling credit, construction, house price and consumption cycles that vary across countries.
\end{abstract}

Key Words: financial crisis, house prices, credit crunch, subprime mortgages

JEL Classifications: R21, G18, E51, E21, C51, C52 


\section{Introduction}

Financial crises can have a lasting and notable effect on economic activity when they reflect the unwinding of financial imbalances that funded real sector imbalances. For example, the stock market crash of 1987 did not result in substantial economic weakness for two reasons. First, the fall in stock prices effectively unwound increases in stock prices between December 1986 and September 1987 that were too short-lived to materially affect saving and capital investment, and second, the policy response was fast and strong enough to prevent lasting damage to the financial system. In contrast, many of the financial innovations this decade fueled not only a financial sector boom, but in the context of low interest rates, also a house price and consumption boom in the UK and US, both of which also suffered substantial damage to their financial systems. Clearly, housing developments are intertwined with-and integral to-the crisis that has gripped financial markets since August 2007 and then escalated to a near complete paralysis of credit flows in late 2008. Although private financial flows have resumed, the recovery in credit markets is still in train and far from complete.

There are a myriad of contributing factors and lessons to be learned from the current crisis, far too many to review in this study (for more details, see, for example, IMF, 2009, and Acharya and Schnabl, 2009). Instead, this article focuses on key aspects of the inter-play between financial innovations and housing in generating and propagating the financial and economic crisis facing the global economy. We concentrate on the U.S. housing boom and bust, where innovations played more of a role than in most other countries, making comparisons mainly with the UK which experienced large financial innovations at different times.

From our perspective, standard analytical frameworks are incomplete in two critical ways that hamper their ability to analyze the causes and the impact of the current crisis. First, they 
collateral was lower and more stable, higher house prices had less of an effect on non-housing consumption during the boom. Nevertheless, many less housing-sensitive economies were not immune and slowed not only from falling net exports to the U.S. and UK, but also from a rise in financial frictions transmitted by a jump in worldwide liquidity risk premia, the souring real estate exposures of many financial institutions and the decline in prices of illiquid financial assets. We conclude by reviewing key findings from recent research on the inter-play between finance, housing, and consumption, and then draw lessons from them regarding financial stability. Chief among these are the importance of recognizing how financial innovations can affect the behavior of house prices and how their broader economic impact differs across countries and over time. Such distinctions have important implications not only for the real estate exposures of lenders, but also for financial and economic stability.

\section{Factors Contributing to the Build-Up and Bursting of the U.S. Housing Bubble}

In many respects, the rise and fall of nonprime mortgages in the U.S. has many of the classic characteristics of financial bubbles discussed by Kindleberger and Aliber (2005), among others. (1) New innovations initially work well, yielding above normal returns. (2) Overoptimism about subsequent returns then fuels an over-investment in the new product; this initially spurs large increases in asset prices. (3) These factors alone are usually insufficient, as some source of funding is needed to sustain the build-up, typically in the form of increased leverage and liquidity in the financial system. (4) If there is a perception that the innovation is fundamentally changing the structure of a market ("this time it's different") or agents use the recent past as a guide, the excess investment and asset price appreciation will be amplified. (5) The combination of these factors gives rise to an asset price bubble. Then an event sparks a downward reassessment of the new asset and price expectations, which, in turn, unwinds the 
over-optimism (at 2 above) and triggers the bursting of a bubble. We see noise and momentum trading, much along the lines of Piazzesi and Schneider (2008) and Scheinkman and Xiong (2003), as playing a role in the building of the nonprime mortgage bubble, through the interaction between housing market inefficiency and expectation formation.

\subsection{The Role of Financial Innovation}

By the mid-1990s, prime U.S. borrowers obtained conventional mortgages from banks, which held the loans in portfolio and funded them with deposits, or from originators who sold conforming loans to Freddie Mac and Fannie Mae (Figure 1). These government sponsored enterprises (GSEs) packaged the loans into residential mortgage-backed securities (RMBS), which the GSEs funded by issuing their own debt or by selling them to investors, whom the GSEs insured against mortgage default. Seeing the GSEs as backed by the U.S. government, investors viewed GSE-issued debt and RMBSs as posing low default risk. In addition, some nonprime borrowers obtained loans from the Federal Housing Administration (FHA) which imposed a minimal down-payment, levied an insurance premium and limited debt service ratios. However, owing to the FHA limits on loan size and debt service ratios, FHA loans were a small share of the mortgage market in the pre-subprime era. In recent years, private nonprime mortgages gained market shares peaking at 40 percent of home purchase mortgage originations in 2006, owing to their much more lax limits on LTV (loan to value) and debt-service ratios.

The rise in LTV ratios and in the nonprime share of mortgage originations over 2000-05 likely reflects the combination of financial innovations that fostered the securitized financing of subprime mortgages (DiMartino and Duca, 2007). The adoption of credit scoring technology enabled loan originators to sort nonprime applicants and price the risk of nonprime mortgages. This left the problem of how to fund nonprime loans, many of which were too risky for regulated 
banks to hold in portfolio or would expose investors to high and uncertain default risk, if packaged into homogenous securities.

The funding problem was addressed by two types of structured financial innovations: the issuance of nonprime mortgage-backed securities that were either packaged into collateralized debt obligations (CDOs) or had default insurance from credit default swaps (CDSs). To make a CDO marketable, its structure divides income streams from mortgage payments into tranches assigned different credit ratings (Figure 2). The tranches for the first streams of income have the highest credit rating reflecting the lowest default exposures, with the remaining tranches having successively weaker credit ratings based on increasingly lower claims on the underlying mortgages' cash flows. If default exposures are perceived to be low, the highly rated tranches would make up the bulk of nonprime mortgage CDOs, as was typical from about 2003 until early 2007. Unfortunately, these perceptions proved faulty, undermining the use of CDOs as a means of protecting investors from default risk on nonprime RMBS. The unregulated and incomplete insurance offered by CDS shared the same fate (DiMartino, Duca, and Rosenblum, 2007).

\subsection{What Gave Rise to Over-Optimism About the Subprime and Other Innovations?}

The misjudgment of the probability of subprime mortgage default and loss given default plausibly arose from the difficulty of forecasting default losses based on a short history. For example, the Mortgage Bankers’ Association data series only start in 1998. The data show that the past due rate on subprime loans (delinquent loans plus those in the process of foreclosure) rose heading into the 2001 recession, but fell rapidly from 2002 to 2005 as the economy recovered. This pre-2006 pattern suggested that as long as job growth continued, the past due rate would remain low (e.g., Vitner and Iqbal, 2009). Indeed, the subprime past due rate 
(SubPastDue) appears well explained by the following model based on year-on-year nonfarm job growth (Jobs) estimated over a 1998:q1-2005:q4 sample period:

$$
\begin{aligned}
& \text { SubPastDue }=12.53^{* *}-1.16^{*} \text { Jobs }_{\mathrm{t}}^{* *}+0.65^{*} \text { Jobs }_{\mathrm{t}-4}{ }^{* *} \text {, } \\
& \text { (77.92) (-11.34) (7.00) }
\end{aligned}
$$

where $\rho=0.25$, DW $=1.91$ and $\mathrm{R}^{2}=0.89 .{ }^{1}$ However reasonable the fit of the above equation appears and however tempting it may have seemed to focus on job growth as an indicator of risk, the model ignores two other important factors that reduced past due rates over 2002-05. First, interest rates fell in the early 2000s, which lowered the base interest rate (usually LIBOR), off which nonprime mortgage rates are reset. This limited any jump in rates when initial teaser interest rates expired. Second, and more importantly, was the rapid rise in home prices, which enabled troubled borrowers to either sell their homes and pay off their mortgages, or resolve late payments by borrowing more against earlier capital gains. Although earlier research on prime mortgage defaults implied a role for house price appreciation, ${ }^{2}$ the fluctuations in conventional mortgage foreclosure rates were much greater after 2006 mainly because the house price swings were much greater than had been forecasted. This was even more the case for nonprime mortgages, owing to the highly nonlinear incentive to default as home values plunge below mortgage principal levels, and to the higher initial LTVs of subprime versus prime mortgages, which make subprime mortgages holders more likely to experience negative equity when house prices fall. When interest rates rose and house prices started to fall in 2006, the past due rate on mortgages began to rise sharply despite continued job growth. Indeed, although the job growth model appeared to track subprime past due rates well through the mid-2000s, it generates a poor out-of-sample, static forecast of 2006-08 (Figure 3).

\footnotetext{
${ }^{1}$ The equation was estimated using the Cochrane-Orcutt transformation, to eliminate residual autocorrelation. tstatistics are given in parentheses. ${ }^{*}$ and ${ }^{* *}$ denote statistically significant coefficients at the $5 \%$ and $1 \%$ levels.

2 E.g., Deng, et al. (2000), Kau, et al. (1992), and Vandell (1995).
} 
Large, unanticipated declines in house prices, probably explain why forecasting models that omitted house prices as an explanatory variable under-predicted the run-up in the subprime past due rate. ${ }^{3}$ To illustrate this, the 3-month LIBOR-Treasury rate spread (TED) and year-overyear house price appreciation (HP4) are added to the earlier model which is estimated over 1998:q1-2005:q4:

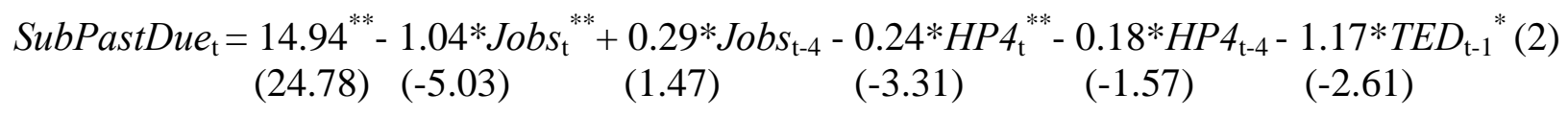

where $\rho=0.74$, DW $=2.04$ and $\mathrm{R}^{2}=0.971$. The pseudo out-of-sample static forecasts from this model, based on actual realizations of the explanatory variables, tracks the subprime past due rate reasonably well unlike the jobs-based model (Figure 3). However, the sharp changes in house price appreciation were largely unanticipated - otherwise many subprime loans and RMBS would never have been created owing to the losses that lenders and investors later suffered.

By way of illustration, consider the pseudo out-of-sample forecast generated by assuming that house prices continued to appreciate at the 10.3 percent year-on-year rate of 2005:q4. With only negative job growth and TED spread effects, this naïve forecast yields only a small rise in the past due rate. If instead the path of house price appreciation followed actual data through 2006:q3, slowed a little further to 5 percent by 2006:q4 and remained at 5 percent, the forecast path tracks just under half of the actual rise in past due rates.

The role of house price appreciation in these forecasts is consistent with micro-level findings that price surprises were a large source of unanticipated subprime losses (Gerardi, Lehnert, Sherlund, and Willen, 2008; Mayer, Pence, and Sherlund, 2009; Sherlund, 2008) and that foreclosures most commonly arise from a combination of negative income shocks and

\footnotetext{
${ }^{3}$ Some forecast failure would still have occurred in models including house prices, given their unanticipated decline.
} 
negative housing equity (Foote, Gerardi, and Willen, 2008; Foote, Fuhrer, Mauskopf, and Willen, 2009). ${ }^{4}$ In an econometric sense, over-optimistic forecasts of the past due rate on subprime defaults can plausibly be explained by short-sample problems and resulting omitted variable biases, coupled with over-optimistic forecasts of on-going house price appreciation. For example, forecasts from job-based models of loan quality lagged behind the run-up in subprime delinquencies (Vitner and Iqbal, 2009), and the fit of standard default models deteriorated (Rajan et al., 2009). In addition, standard U.S. house price models that did not control for shifts in credit standards broke down during the U.S. subprime boom and bust (Duca, Muellbauer, and Murphy, 2009a).

\subsection{Sources of Leverage and Liquidity during the Subprime \& Structured Finance Boom}

Leamer (2007) and Taylor (2009) inter alia argue that Federal Reserve cuts in short-term real interest rates to zero in 2003-4 led to the subprime bubble. However, no bubble or unsustainable easing of credit standards arose after 1992-93, when the real fed funds rate also fell to zero. In addition, consumption and housing were generally stronger during the mid-2000s than conventional models predicted, accounting for income and mortgage interest rates. This unusual strength was accompanied by large surges in mortgage equity withdrawal (MEW) and refinancing activity_especially during the 2001 high-tech recession and after September 11, 2001. 5

\footnotetext{
However, the warning signals would have been perceived much sooner and risks assessed less badly.

${ }^{4}$ The importance of price appreciation and negative net equity positions explain why prime and subprime loan default rates move together. In addition, vintages of seasoned Alt A mortgages have progressively higher proportions of no- or low-documentation of income (Credit Suisse 2007) and higher loan loss rates (see Jaffee, 2009, and Mayer, Pence, and Sherlund, 2009), suggesting that an errors-in-variables problem from overstatements of borrower income contributed to underestimates of nonprime mortgage defaults.

${ }^{5}$ If consumption and housing were stronger than predicted by models that included income and interest rate terms, the Leamer (2007) and Taylor (2009) explanations would need to also argue that the low interest rate policies of the Federal Reserve induced an easing of non-price credit terms, but the earlier low real federal funds rates of the early 1990s did not spur as sharp a rise in LTV ratios as in 2003/2004 (see Duca, Muellbauer, and Murphy, 2009a).
} 
A more balanced explanation of the subprime bubble is that low interest rates, a major easing of mortgage credit standards and an increased ability to tap housing wealth boosted overall household spending. The extra borrowing was funded not so much by money supply growth, but rather by securities issuance, bolstered by increased leverage and capital inflows. A role for the latter factor is suggested by post-1990 trends in the US current account, which widened as the consumption and residential construction shares of GDP rose (Figure 4). Of course endogenous factors affect current account trends, but given the boom in household spending and drop in the personal saving rate, capital inflows accommodated at least some of the higher borrowing.

Some argue that large capital inflows to the U.S. from China and other countries were partly or largely behind the weakening of credit standards and the accompanying growth in securitization and structured financial products (Corden, 2009). It is unclear how much financial innovation in the U.S. was caused by global imbalances because a large current account swing occurred in the 1980s without a major U.S. housing boom-bust. The fact that the surge in the consumption share of US GDP was larger in size than the widening of the current account deficit suggests roles for other factors. Nevertheless, in the absence of large capital inflows, US interest rates would have been higher given the higher level of credit demand.

This is where higher leverage played a critical role, manifesting itself in three ways. First, although Freddie Mac and Fannie Mae did not package a substantial share of nonprime mortgage-backed securities, they purchased or guaranteed substantial amounts of private label RMBSs. They did so partly to meet their annual public policy goals of devoting a minimum percent of their business to expanding affordable housing, the two GSEs holding $\$ 253$ billion in 
private label RMBS by mid 2007 (Frame, 2008, p. 129). ${ }^{6}$ Second, the prime mortgages packaged into RMBS by the two GSEs often funded the 80 percent first liens on many home purchases, the other 20 percent being funded by "piggyback" second mortgages which were not guaranteed by the GSEs (Duca, 2006a, p. 7). In these two ways, the GSEs (with help from foreign purchases of RMBSs) indirectly contributed to the easing of U.S. mortgage credit standards in the early and mid-2000s. Thirdly, structural incentives encouraged the GSEs to issue debt which financed purchases of their own and private label RMBSs (Jaffee, 2003; and Frame, 2009). This initially increased their profits, leverage, and mortgage lending.

The GSEs were not alone. Some large US bank holding companies created off-balance sheet entities, such as special investment vehicles (SIVs), to raise their leverage (Acharya and Richardson, 2009). These SIVs funded purchases of risky or longer duration assets (e.g., nonprime RMBS's and CDS's) by issuing short duration debt, initially given high credit ratings. Although the profits from any excess of asset returns over debt payments flow to the bank holding company, debt holders bore the downside risk of losses, despite these holding companies posting little if any initial capital stakes. In addition, banks lent to hedge funds making highly levered, nontraditional investments. Investment banks also increased their exposure to nonprime mortgages and leverage (Adrian and Shin, forthcoming, 2008). This trend accelerated after the Securities and Exchange Commission (SEC) raised the limit on the leverage ratios of the brokerage units of large investment banks from 15:1 to 33:1 in 2004 (Labaton, 2008). Smaller capital cushions made investment banks more fragile, contributing to the closure, sale, or conversion into commercial banks of what had been the five largest U.S. investment banks.

\footnotetext{
${ }^{6}$ The GSEs' annual housing goals are set by the U.S. government. The estimates of the GSEs' exposure to nonprime mortgages, including guarantees, in Calomiris and Wilson (2008) are higher.
} 
Higher leverage was accompanied by greater use of derivatives that enhanced the liquidity of assets backed by or derived from nonprime assets. As Acharya, et al. (2009) stress, the rise of credit derivatives, primarily CDOs and CDSs, occurred in an unregulated over-thecounter (OTC) market, where the bilateral nature of trades made the value of the derivatives nontransparent since the exposures of counter-parties were often unclear. This shortcoming became apparent as subprime loan losses unexpectedly rose during 2007. Then credit enhancements that had bolstered investor appetites for nonprime assets became prohibitively expensive or unavailable, adding to the collapse of funding for nonprime mortgages in $2007 .{ }^{7}$

Other factors fostered excess levering during the boom and delevering in the bust. On the demand side, tax deductibility of mortgage interest encouraged households to take on leverage offered by lenders, as did the limited mortgage default liability of most US households. Other countries, such as Denmark and the UK, removed the tax deductibility of mortgage interest, which, ceteris paribus, should have muted the recent boom. In other countries, the tax regime favored rental housing (e.g., Germany) or was tenure neutral or had different effects on the recent cycle. ${ }^{8}$ On the supply side, the risk appetite of global investors was unusually high from mid-2003 to mid-2007 before plunging in the summer of 2007 (e.g., Credit Suisse global risk appetite index). Some of the diminished risk appetite of investors and lenders stemmed from bad outcomes on highly levered non-housing investments. Finally, the more muted business cycle from 1984 to 2007, the so called "great moderation", fostered complacency among borrowers and lenders.

\footnotetext{
${ }^{7}$ Note: misaligned incentives to originate and sell nonprime mortgages suggest that reforming regulations on securitization may be needed to limit excessive levering and risk-transferring by mortgage originators.

8 The implications of international differences in tax regimes and institutions are discussed by Englund (2003), European Central Bank (2003, 2009), and MacLennan, et al. (1998).
} 


\subsection{Market Frictions and House Price Expectations}

There is much evidence that the presence of large transactions costs for residential real estate assets that can give rise to serial correlation in house price movements. There are not only large pecuniary costs of moving and non-pecuniary costs of relocating a family, but also sizable direct transactions costs. For example, in the US standard real estate agent fees are 5 to 6 percent of the sales price, with home sellers paying some legal and other fees. If a home is vacant, there are additional carrying costs for the six-month period it normally takes to sell a house. In contrast, low transactions costs on standard financial assets helps reduce near-term serial correlation in their excess returns, making their short-run excess returns more difficult to predict.

Compounding these effects is the thinness of housing markets. Average annual turnover rates for existing homes are 5 to 6 percent in the US, far below the $100 \%$ annual turnover of stocks traded on the New York Stock Exchange. Low turnover and the heterogeneity of neighborhoods, individual lots and structures - makes it difficult for households to have accurate expectations about home values. For example, a weakening of credit standards which enabled just 1 percentage point more of the population to buy homes would initially boost the flow demand for housing by about 20 percent. In this way, the sequential weakening of standards during the US subprime boom (Duca, Muellbauer, and Murphy, 2009a) produced a series of positively correlated increases in house prices. Conversely, a positive uptrend could reverse if a serially correlated wave of foreclosures subsequently boosted the supply of houses on the market. Recent research by Piazzesi and Schneider (2009) demonstrates how the presence of a small number of optimistic traders in thinly traded markets, coupled with an easing of credit conditions, can induce expectations of higher house prices, as seen during the US housing boom. 
With large transactions costs and thin trading, it is not surprising that house price appreciation and excess returns on house prices are serially correlated. Hamilton and Schwab (1985), Case and Shiller (1989, 1990), Poterba (1991) and Meese and Wallace (1994) find that house price changes are positively correlated and past information on fundamentals can forecast future excess returns. ${ }^{9}$ Hamilton and Schwab (1985), Capozza and Seguin (1996), and Clayton (1997) find evidence against the hypothesis of rational home price expectations, while Goodman and Ittner (1992) show that households inaccurately gauge the market value of homes. Under circumstances fostering serial correlation in excess housing returns, it is not surprising that the bubble builder and bubble burster dynamics stressed by Abraham and Hendershott (1996) are common features of most estimated house price models. In the short-run, these dynamics amplify the house price effects of shocks not only on housing demand, but also on the supply of credit in a similar direction, by encouraging lenders to forecast rising collateral prices during booms and falling values during busts.

\subsection{The Combination of Bubble-Feeding Factors}

The combination of the above factors fed the recent housing bubble. In the US and to a lesser extent the UK, new financial instruments induced an unusual weakening of credit standards in the form of subprime lending that pushed up housing demand in somewhat thin real estate markets. The resulting boost in house prices initially helped maintain the quality of earlier subprime mortgages, induced over-optimism about the downside risks of nonprime loans, and fed expectations of future gains. In turn, these factors further increased the demand for housing and the availability of nonprime mortgages, also boosted by increased RMBS financed leverage. After mortgage rates finally started rising in 2005, house price appreciation slowed in 2006. By

\footnotetext{
${ }^{9}$ Indeed, Blanchard and Katz (1990) find evidence that housing markets usually clear via in- or out-migration, and take 3-4 years for local real house prices to hit bottom following a negative, relative (local) shock to labor demand.
} 
late 2006 and early 2007, nonprime loan quality deteriorated and the process started to reverse. In this narrative, the often over-looked inter-relationship between mortgage credit standards and housing demand combined with classic characteristics of financial bubbles created a boom-bust in American real estate markets. Non-credit housing factors, such as immigration, strong income growth from economic reform, and changes in family structure also played an important role in inducing the housing boom-bust cycle seen in Ireland, Spain, and the UK (Murphy, 2006; Cameron, et al. 2006). Blake and Muellbauer (2009) confirm the role of shifts in credit availability in these countries, however. Demographics played a smaller role in the recent house price swings for the U.S. (Duca, Muellbauer, and Murphy, 2009), where the dire predictions of Mankiw and Weil (1989) for the 1990s did not come to pass, largely because their model did not accurately measure real user costs, as stressed by Hendershott (1992).

\section{The Importance of Financial Innovations for House Price Behavior}

Although the recent financial crisis has had a global impact, the channels of these effects vary across countries, reflecting not only differences in the structure of housing and mortgage markets, but also heterogeneity in the structures and linkages of macro-economies reviewed in the next section. In part reflecting the adoption of similar monetary policies, there has been an increase in the correlation of national house price movements from the mid-1990s to the mid2000s. Nevertheless, there are substantial cross-country differences in house price trends (Ahearn et al., 2005, and Girouard et al., 2006). Between 1999 and 2006, real house prices jumped in many OECD nations, rose more modestly in several countries, and were flat in three (Japan, Germany, and Switzerland). In addition, while losses on nonprime mortgages have damaged the capital positions of financial firms across the globe, those losses disproportionately 
reflect mortgage defaults in the U.S., where an easing of mortgage credit standards played a role in later generating loan defaults.

A useful framework for addressing these patterns augments a standard model of house prices for credit availability (e.g., Meen, 2001, or Muellbauer and Murphy, 2008). The standard house price equation is obtained by inverting the demand equation for housing services (assumed proportional to the housing stock) and treating the housing stock as fixed in the short run. Let housing demand be given by:

$$
\ln h=-\alpha \ln u c+\beta \ln y+\gamma C C I+\delta z
$$

where $h$ is the per capita housing stock, $y$ is real per capita income, $u c$ is the real user cost or rental of housing, $C C I$ is an index of credit conditions reflecting mortgage credit standards (described below), and $z$ represents other demand factors (e.g., age composition and immigration). The own price elasticity of demand is $-\alpha$ and the income elasticity is $\beta$. Real user costs adjust nominal mortgage rates for several factors including expected capital gains, with the usual approximation being $u c=h p\left(r+\delta+t-h \dot{p}^{e} / h p\right)$, where $h p$ is the real house price, $r$ is the real after-tax interest rate of borrowing, possibly adjusted for risk, $\delta$ is the depreciation rate, $t$ is the property tax rate, and $h \dot{p}^{e} / h p$ is the expected real rate of house price appreciation. If bubble builder and bubble burster dynamics are present, then a positive housing demand shock drives up house price appreciation, thereby lowering user costs and further feeding housing demand and price appreciation.

The credit conditions index is negatively related to mortgage credit standards for marginal, first-time home-buyers. Such standards may reflect maximum limits on initial loan-tovalue (LTV) and mortgage payments-to-income ratios and minimum credit scores. Easier credit 
standards on the marginal home buyer raise the effective demand for housing services. Rearranging eq. (3) yields the inverted demand specification for real house prices:

$$
\ln h p=\left(\beta \ln y-\alpha \ln \left(r+\delta+t-h \dot{p}^{e} / h p\right)+\gamma C C I+\delta z-\ln h\right) / \alpha
$$

In practice, expected capital gains are not directly observed and must be proxied in some fashion. Real user cost estimates may be negative (especially in the UK), so the log formulation is not always feasible, as discussed in Cameron, et al. (2006).

The credit-augmented inverted demand framework has several implications for the crosscountry pattern of house prices (see Table 1). ${ }^{10}$ At one extreme, among nations with subdued demand for housing owing to declining demographic factors and limited financial liberalization, real house prices can trend down (e.g., Japan and Germany in the 2000s, Figure 5). Even if credit markets are poorly developed, rising income coupled with a highly inelastic supply of housing can give rise to housing bubbles (e.g., Japan in the 1980s). In nations with welldeveloped credit markets, standard non-credit factors can greatly boost housing demand, inducing large swings in home prices (e.g., Spain in the 2000s). In other countries, such as Italy, that experienced only modest liberalization and moderate increases in housing demand pressing up against inelastic supply, house price have notably increased but not outside the bounds of past cycles. In cases like this, house price models without credit (or housing supply) variables can track house prices reasonably well, though for Germany housing supply plays a crucial role (Blake and Muellbauer, 2009).

But if two factors - easier credit standards arising from financial liberalization and large swings in mortgage interest rates - are added in, house price fluctuations may be amplified

\footnotetext{
${ }^{10}$ Similar credit liberalization implications can arise in an arbitrage-based, house price-to-rent framework (Kim 2007), as verified by Duca, Muellbauer, and Murphy (2009a), but the price-to-rent approach is infeasible in many countries where nontrivial rent regulations cast doubt upon the implicit arbitrage assumptions of that framework.
} 
beyond what standard models suggest. The ensuing housing boom and bust may be marked by loan losses and bank failures. This pattern also describes the house price boom-bust of the late 1980s and early 1990s which followed mortgage market liberalizations in Scandinavia (Girouard and Blondal, 2001) and the UK (Muellbauer and Murphy, 1997; Muellbauer, 2009), and the current UK cycle (Blake and Muellbauer, 2009). Girouard et al. (2006) and the European Central Bank (2009) report notable mortgage innovations and liberalization (increased access to nonconforming, exotic, and investor mortgages) in recent years in many countries other than the US:- Australia, Finland, France and Spain (longer mortgage maturities), the UK (more flexible mortgages), Denmark (more variety of mortgage interest rate products), Ireland (longer mortgage maturities and more investor mortgages), and the Netherlands (rise of interest-only mortgages). Blake and Muellbauer (2009) confirm these findings for a number of European countries, while Williams (2009) does so for Australia. Fernandez-Corugedo and Muellbauer (2006) provide time series evidence of liberalization in the UK, while Duca, Muellbauer, and Murphy (2009a) do so for the U.S. Many of these countries saw sharply higher house price-to-rent ratios in the recent boom than earlier (Figure 6). ${ }^{11}$

Financial liberalization also alters the relative impacts of nominal versus real interest rates on housing demand and consumption. For the UK, Cameron et al. (2006) show how financial liberalization, as tracked by the credit conditions index in Fernandez-Corugedo and Muellbauer (2006), lowered the elasticity of house prices with respect to nominal interest rates, while raising it with respect to real interest rates. Aron, Muellbauer, and Murphy (2008) obtain a

\footnotetext{
${ }^{11}$ Similar cross country inferences arise using house price-to-income ratios, but the patterns are less clear in twodimensional diagrams as these ratios are more sensitive to interest rates and housing supply than are price-to-rent ratios. Two dimensional depictions of relative house price movements are inevitably limited. For example, changes in house price-to-rent ratios also depend on variation in rent controls and interest rates across countries and over time, but most of the recent variation is due to changes in credit conditions and to similar interest rate movements. Although rents may be measured with error (Meese and Wallace, 1994), it is unlikely that the errors are sizable
} 
similar result for the interest rate elasticities of consumption in the UK, as does Williams (2009) for Australian house prices. For the U.S., Duca (1996) finds that the interaction of mortgage rates with deposit regulations affected construction prior to deregulation, while Duca, Muellbauer, and Murphy (2009a) find that such interactions had affected the short-run dynamic patterns of house prices.

In the interesting case of Spain, house prices were pushed up by strong housing demand, propelled in large part by strong income growth, the lagged effects of lower interest rates from joining the Euro, northern European demand for second homes, household formation that grew faster than population, and strong immigration flows (Cortina, 2009). ${ }^{12} \quad$ Relative to the U.S., explicit limits on LTVs for mortgages funded by the securities market were not weakened as much owing to regulations limiting the use of covered bonds to funding residential mortgages with LTVs below 80 percent (IMF, 2006, pp. 16-17). However, these explicit regulations may have been partly circumvented by using inflated house appraisal values rather than transactions prices to calculate the LTVs. For this reason, some easing of LTV limits probably contributed to the run-up in Spanish house prices, though LTVs likely remained lower than in the US where average LTVs on subprime mortgage originations jumped to a high of 94\% in 2006 (Credit Suisse, 2007) and 100\% financing was once explicitly available for many households.

Although the cross-country patterns are broadly consistent with the implications of the credit-augmented, inverted housing demand model, there has been little empirical testing of the implications of financial liberalization in either calibrated models or estimated econometric models. Exceptions to the latter include Duca, Muellbauer, and Murphy (2009a) and Cameron,

enough to overturn the large observed movements in price-to-rent ratios in some countries and alter the qualitative patterns noted above.

12 The rise in defaults has been higher for immigrants (Cortina, 2009), whose income is less protected by safety nets and whose non-pecuniary costs of losing a home may be less than those of native citizens (The Economist, 2007). 
Muellbauer and Murphy (2006). The former uses cyclically-adjusted time series data on LTV ratios for first-time home-buyers (and deposit regulation variables) to control for mortgage liberalization in the US, whereas the latter uses a broader index of household financial liberalization to analyze UK house prices. ${ }^{13}$ Both studies find that it is critical to control for mortgage liberalization in order to obtain robust and sensible long-run econometric relationships as well as data coherent models of short-run changes in real house prices. In addition, Muellbauer and Murphy (2008) suggest that liberalization induced a larger house price boombust during the 1980s and early 1990s in the UK, where highly inelastic housing supply fed into price dynamics, than in the U.S. They argue that mortgage liberalization played a somewhat smaller role in sparking and amplifying the impact of other demand variables during the recent UK home price boom-bust cycle, which appears to owe more to traditional demand factors and unusually high immigration pushing houses prices up in the face of inelastic housing supply. However, increased securitization and the increased resort to money market funding by lenders such as Northern Rock very likely gave some impetus to house price appreciation, as supported by the empirical findings of Blake and Muellbauer, 2009.

In the case of the recent US house price boom, Duca, Muellbauer, and Murphy (2009a) find that an unsustainable and substantial mortgage liberalization induced a large house price bubble, even though the price elasticity of housing supply in the US is high relative to that in other countries. Similarly, Williams (2009) finds that mortgage liberalization played a key role in the extended house price boom in Australia, where housing supply is often limited by thin strips of land between mountains, the outback and the coast.

\footnotetext{
${ }^{13}$ Fernandez-Corregudo and Muellbauer (2006) construct their UK index using micro data from a survey of mortgage lenders. They examine changes in LTV and loan-to-income ratios of first-time home-buyers along with other information on consumer and mortgage debt. Using a 10-equation system with controls for relevant economic and demographic factors, they extract a single time-varying index of exogenous credit conditions.
} 
The differential role played by easier credit standards in the US and the UK has been borne out by the much larger-sized jumps in the foreclosure and delinquency rates in the US. This is partly explained by the greater negative consequences for defaulting households in the UK. Similarly, the differential role played by the price elasticity of housing supply is reflected in the larger swing of per capita housing starts in the US versus the UK. It is also apparent in the larger swings in US home price changes in regions where topography and regulation restricted the supply of new building lots more than in other regions. Broadly, US housing demand was boosted by common factors, such as low interest rates, easier credit standards, and income growth. But the price swings were larger in the Northeast and West regions of the US (Duca, Johnson and Muellbauer, 2009), while the swing in home building was larger in the South, where the supply of land is much more elastic owing to zoning and topography. It is clear that differences in the timing of large price increases across countries (Figure 7) reflect differences in housing supply elasticities, as well as differences in the timing of changes in housing demand,

The importance of financial liberalization and housing supply for home prices is also relevant for policies aimed at increasing home-ownership among the young. For example, in areas with limited land supply, government mortgage programs providing easier LTV and debtservice-ratio maximums often have the unintended consequence of driving up house prices, while inducing little expansion of housing supply. In such areas, higher density or cluster zoning may be more effective in boosting homeownership. Similarly, the adoption of unviable, easier credit standards during the U.S. subprime boom may have done little to raise long-term homeownership rates among the young in areas with inelastic housing supply. To some extent, regulation limiting subprime mortgages in the U.S. was initially thwarted by concerns that stringency would be a barrier to homeownership. The huge swings in housing demand and 
prices induced by the subprime and Alt A mortgage boom led to large loan losses on prime mortgages that had default insurance from Fannie Mae and Freddie Mac. The GSEs also suffered large losses on the subprime RMBS that they had purchased to meet the public goals of raising homeownership. Ironically, the reluctance to regulate nonprime mortgages and the pursuit of home-ownership goals of Fannie Mae and Freddie Mac, via subprime MBS purchases, partially undermined the funding —and thereby the stability—of prime mortgage lending in the U.S., culminating in both GSE's being placed into conservatorship and under the control of the U.S. Treasury. The under-weighting of these risks may reflect the fact that the impact of mortgage liberalization on house prices was not sufficiently understood by the private and public sectors.

\section{Broader Economic Impact of the Housing Boom-Bust}

The real economic impact of swings in housing demand differs across nations and time, reflecting not only housing construction effects (section 4.1), but also three spillover effects on broad economic activity: the impact of housing collateral ("wealth”) on consumer spending (4.2); the intra- and inter-national effects of such movements on the condition of the financial sector and thereby the availability of credit (4.3); and the international transmission of slowdowns in housing-sensitive economies via net exports—a topic beyond the scope of this article.

\subsection{Housing Construction Effects}

The construction effects of the housing bust have also varied with supply and demand conditions across countries. Where the supply of housing is relatively price elastic (e.g., Ireland, Spain and the US), swings in effective housing demand have induced large swings in construction (Figure 8), whether stemming from an easing of credit standards (the US) or from other demand factors. The effects on US construction were stressed in earlier work on the US 
housing crisis by Case and Quigley (2008) and Leamer (2007). In the UK where there was also a boom and bust in housing demand, the more constrained supply of housing prevented much of a run-up in building during the boom, despite large increases in house prices. ${ }^{14}$ Only recently has UK construction shown a notable response, reflecting the unusual plunge in housing demand. In Japan and many other Western European countries, the demand for or the supply of housing was restrained and movements in total construction were muted (Figure 8, Table 1).

It is a mistake to assume that countries with more responsive housing supply are necessarily more stable than others because the supply response mutes the response of house prices to demand fluctuations or because the collateral role of housing is limited. For example, in the US and Spain the residential construction share of GDP has fallen by almost 2 percentage points in the last two years (Figure 8). ${ }^{15}$ In contrast, there have been much milder declines in the rest of the Euro Area and the UK so far, and even slight rises in some countries during late 2008.

As a consequence, large swings in housing demand can have destabilizing domestic effects via construction or house prices, the latter of which can alter consumer spending directly or indirectly via their impact on the solvency and loan policies of lenders. For example, in some US regions (e.g., the non-coastal South) where housing supply has been elastic and house price increases had been more muted, the swing in housing demand notably affected home construction. In other areas, where the response of housing supply was more limited and house prices surged during the boom, the impact of house prices has particularly affected consumer

\footnotetext{
${ }^{14}$ The recent construction and price cycles for commercial real estate differ from those of residential real estate in both the UK and U.S., where the commercial cycles tend to lag behind the residential cycles (Meeks, 2008), partly reflecting differences in time to build.

${ }^{15}$ Some of this strong response in the US is consistent with earlier evidence of feedback effects of lagging house price appreciation on US home construction, as reported in Muellbauer and Murphy (2008). Mayer and Somerville (2000a) argue that residential construction responds not to the level of real house prices, but to the rate of appreciation, reflecting builder incentives to earn rents on the land component of house prices.
} 
spending (Case, Quigley, and Shiller, 2005), especially on consumer durables which, in turn, has slowed the economy of the more manufacturing-oriented Midwest region.

Nevertheless, not only does the responsiveness of housing supply differ across countries and regions, but there are good reasons to suggest that it may also vary over time within a given area. A large number of studies argue that restrictions on land supply have a significant negative effect on the responsiveness of new house building to house prices, and there are concerns that housing supply has become less flexible in the Northeast and Pacific regions of the US. ${ }^{16}$ As a result, historical-based forecasts of house prices or of the upside or downside risks to house prices may be undermined by unforeseen changes in zoning or other supply fundamentals.

\subsection{House Prices and Consumer Spending}

\subsubsection{House Prices and Aggregate Consumption}

Estimates of the "impact" of housing wealth on consumption vary widely across countries, ranging from traditional and significant m.p.c. estimates of 3 to 6 percent in the US (Englehardt, 1996; Brayton and Tinsley, 1996) to negative in Japan (Muellbauer and Murata, 2009). ${ }^{17}$ Moreover, where wealth effects appear sizable, they vary over time and have become larger, as in the US (see Carroll, Otsuka, and Slacalek, 2006 and Slacalek, 2009). What can explain these patterns?

In a world of perfect capital markets, imperfect substitution between housing and nonhousing goods and dynastic-Ricardian households, higher real home prices could have small positive or even negative effects on non-housing consumption depending upon whether positive

\footnotetext{
${ }^{16}$ For example, see Titman (1985), Mayo and Sheppard (1991, 1996), Bramley (1993a,b), Evans (1996), Mayer and Somerville (2000a,b), Malpezzi and Maclennan (2001), Swank et al. (2002), Barker (2003), Bramley and Leishman (2005), Green et al. (2005), Quigley (2007), Vermeulen and Rowendal (2007), and Saiz (2008).

${ }^{17}$ Duca (2006b) finds that non-stock market wealth (primarily housing) has a stronger relationship to consumer spending that includes durables, consistent with complementarities between housing and some components of durables, as well as the higher credit and wealth sensitivity of durable spending.
} 
wealth and substitution effects of a permanent rise in relative house prices are offset by the income effect of paying higher prices for housing services (Muellbauer, 2007; Buiter, 2008). It might be tempting to argue that a positive overall housing wealth effect on consumption arises in the US, where a more nuclear family structure implies that Americans worry less about the housing needs of future generations and see higher house prices as raising their lifetime resources for non-housing consumption. But cultural differences by themselves may not be a full or satisfying explanation. Not only are they hard to verify empirically, but cultural factors do not really explain why house price effects have changed within countries, particularly during periods of financial or credit liberalization.

As Muellbauer and Lattimore (1995) and Muellbauer (2007) stress, higher collateral from rising house prices enables homeowners to borrow, who may otherwise face binding credit constraints. By implication, any aggregate observed housing wealth effect is likely limited to (1) individuals or households who are - or fear they might become - credit constrained homeowners, for whom housing wealth affects non-housing consumption via a collateral effect; and/or (2) countries where home-ownership rates are high and credit markets are developed enough to use housing collateral as a means of borrowing to fund non-housing consumption (MacLennan, Muellbauer, and Stephens, 1998). At the macro level, a greater ability to borrow against housing assets could translate into a higher aggregate m.p.c. out of housing wealth.

\subsubsection{Micro-economic Evidence on Housing Collateral Effects on Consumption}

In line with the aggregate evidence, Hurst and Stafford (2004) found that among US homeowners with accumulated real house price gains, those with less liquidity were more likely to have refinanced their mortgage over 1991-94 and devoted higher shares of any equity withdrawn toward non-housing consumption. Consistent with these earlier results, Cooper 
(2009) finds, using later waves of PSID panel data, that housing wealth has a statistically significant impact on US households that are young, have lower liquid asset holdings, or whose current income is at least 10 percent below their average past income. These types of findings are not limited to the US. Campbell and Cocco (2007) find that although positive house price effects on consumption affect many UK households, the effects are stronger for credit constrained, older home-owners. Browning, Gortz, and Leth-Petersen (2008) find that house price appreciation only affected the consumer spending of Danish households with low liquidity.

\subsubsection{Cross-Country Differences in Housing "Wealth” Effects}

Consistent with the collateral view, estimated effects of housing wealth on non-housing consumption vary across countries, largely in accord with differences in the ability to borrow against housing wealth (see Catte, 2004 and Slacalek, 2009). At one extreme is Japan, where credit markets for households are relatively undeveloped, but real land prices are high reflecting the limited supply of building lots owing to topography and agricultural policies. In addition, the combination of an extended-family oriented kinship system and the use of intergenerational (100-year) mortgages to finance high real home prices fosters a dynastic view of housing. As Murata (1999) and Muellbauer and Murata (forthcoming) show, higher real house prices are associated with lower non-housing consumption in Japan, but the effect is small in magnitude albeit statistically significant.

Italy is another country with a less developed mortgage market, mainly because the legal system makes it hard for lenders to access housing collateral in the event of default. There is also an extended-family oriented kinship structure (unmarried adult Italians often reside with their parents). Estimates of the m.p.c. of housing wealth are low, ranging from 2.4 percent (Paiella, 2007) to statistically insignificant (Grant and Peltonen, 2004) and to negative (Catte et al (2006) 
and Kennedy and Andersen (1994)). Interestingly, Grant and Peltonen find that the only significant response of consumption by age group is among the elderly, whose consumption falls when real house prices rise unexpectedly. Older Italians save more when house prices rise, apparently to help their children amass down-payments to buy their own homes. In Spain, where the ability to borrow against housing collateral has been limited, estimates of housing wealth m.p.c.'s are also lower than in the US. For example, Bover (2007) finds an m.p.c. of 2 to 3\%.

In contrast, in Australia, the UK and the US, where credit markets are deeper, it is more common to find statistically significant housing wealth coefficients (Table 2). For example, Dvornak and Kohler (2003) estimate the long-run m.p.c. out of housing wealth at 3 percent in Australia, while in a more complete consumption model that controls for financial liberalization, Aron et al. (2006, 2009) and Muellbauer and Williams (2010) find that this m.p.c. peaks at around 3 percent in the UK and Australia, respectively, but was zero before credit market liberalization. M.p.c. estimates for the US before the subprime boom were usually in the 4 to 6 percent range (Brayton and Tinsley (1996), Englehardt (1996), Peek (1983), and Skinner (1989, 1994, 1996)).

These cross-country patterns are consistent with the model in Aron, et al. (2009), who use a common framework, based on an updated, Ando-Modigliani style consumption function with credit constraints, to model consumption in Japan, the UK and the US. They find no evidence of a significant housing wealth effect in Japan, but positive effects in the UK and the US.

\subsubsection{Evidence of Increasing Housing Collateral Effects on Consumption in the UK, US and}

\section{Australia.}

Theoretical considerations suggest that other things equal, the size of the housing collateral effect depends on the extent of financial liberalization, which may vary over time. For 
the UK, Miles (1992) and Muellbauer and Murphy (1989) provided early evidence of an increased collateral-like impact of housing wealth on UK consumption owing to financial innovation. This added greatly to the consumption boom of the late 1980s; a result further supported by Aron et al. (2006, 2009), who shows that expectations of rising income could not account for much of the decline in the UK personal saving rate during the late 1980s.

There is also a growing literature in recent years documenting a rise in the sensitivity of US consumption to housing wealth. For example, Carroll, Otsuka, and Slacalek (2006) and Case and Shiller (2008) argue that the housing wealth m.p.c. has risen to as high as 9 to 12 percent in the early 2000s, roughly $50 \%$ to $100 \%$ larger than earlier estimates. Much of this rise has been linked to an increased ability of households to tap housing wealth in the form of mortgage-equity withdrawals, as measured by Greenspan and Kennedy (2008). In addition, the collateral effect means that large swings in house prices have a nonlinear amplifying effect on consumption. For example, if real house prices increase substantially, housing collateral as a share of lifetime income and wealth rises. Borrowing will also rise, other things being equal including the ability to borrow against each unit of housing wealth.

In the US, there is evidence that easier credit standards raised permissible loan-to-value ratios for home purchase mortgages and increased the ability of households to borrow against housing equity (Duca, Muellbauer, and Murphy, 2009a and 2009b, respectively). That said, many other estimates of the rise in the housing wealth effect on US consumption may be overstated due to the lack of controls for consumer credit availability. Accounting for such effects, Aron et al. (2009) find that, although m.p.c. estimates for the US have risen, they peak below estimates obtained in studies that do not account for shifting credit constraints (e.g., 
Slacalek, 2009) or which use housing wealth data that pre-date substantial revisions to US Flow of Funds data.

Mortgage equity withdrawal (MEW) became important in the UK from around 1983, when it contributed to the UK "Lawson" consumption and house price boom of the late 1980s and the "Lamont" bust of the early 1990s (Miles, 1992). MEW is defined as the net increase in mortgage debt minus residential investment. Recognizing the potential information in the phenomenon, the Bank of England has been measuring MEW for quite some time (Davies, 2001). MEW reflects borrowing not only through home equity lines of credit, but also by households increasing the size of their mortgages when refinancing them (so-called "cash-out" mortgage refinancings in the US) and by households not fully rolling over their realized capital gains on the sale of a home into the down-payment on the purchase of a subsequent residence. Many macroeconomic forecasters have found MEW series (e.g., Greenspan and Kennedy, 2008) to be useful in gauging US consumption.

Of course, movements in MEW are driven by a combination of endogenous and exogenous factors. For example, MEW reflects exogenous relaxations of mortgage downpayment constraints, which lower the personal saving rate (Englehardt, 1996), and/or increases in the liquidity of wealth, which can boost consumption in ways similar to a relaxation of credit constraints (Carroll and Kimball, 2004). In the US, the latter effects arise from increased tax incentives to use home equity loans, as well as technological innovations that have lowered the costs and raised the ability of households to refinance mortgages. Canner, Dynan, and Passmore (2002) document how proceeds from cash-out mortgage refinancings partially boosted US consumer spending, consistent with the cross-section consumption findings of Hurst and Stafford (2004) and evidence that mortgage refinancing costs have fallen (Bennett, Peach, and Peristiani, 
2001). That MEW measures may be tracking the evolution of wealth elasticities is implied by Duca (2006b), who finds that it is necessary to include measures of both mortgage refinancing and MEW activity in models of consumption to order to obtain long-run income and wealth elasticities of consumption that are stable across sample periods.

Nevertheless, adding MEW terms to consumption function regressions runs the risk of endogeneity bias, because MEW also reflects households' reactions to movements in interest rates and house prices. For example, declines in interest rates set off a surge in both mortgage refinancing and MEW in the US during the 1997-98 and 2002-03 periods. Similarly, the relaxation of down-payment constraints pushed up house prices over 2000-05 (Duca, Muellbauer, and Murphy, 2009a), which induced the 2001-06 surge in MEW. The mixture of exogenous and endogenous factors in MEW helps explain why MEW has not been consistently linked to house price appreciation or interest rate incentives to refinance US mortgages over time, and why MEW's correlation with house price appreciation has generally risen (Figure 9).

The endogeneity of MEW was noted in early analyses of UK consumption (Miles, 1992, and Muellbauer and Murphy, 1997). This endogeneity is addressed in Duca, Muellbauer, and Murphy (2009b) who identify the effects of exogenous financial innovations on the propensity of households to refinance mortgages and engage in MEW activity. This study finds that declines in the barriers to mortgage refinancing had enhanced the liquidity of US housing wealth in the late 1990s, inducing a surge in MEW activity, consistent with the point-in-time analysis of Canner, Dynan, and Passmore (2002). However, Duca, Muellbauer, and Murphy (2009b) find evidence of a pronounced decline in the liquidity of housing wealth since 2006, probably reflecting the interplay of lender's loan losses, higher mortgage default risk and falling home prices. 


\subsection{Transmission to Less Housing Sensitive Economies}

Once the performance of new mortgage products declined and the oversupply of new homes in many housing markets became apparent, lenders suffered large, unanticipated capital losses and tightened mortgage standards. This, in turn, magnified the ensuing house price and construction decline in countries that had experienced a credit-easing induced housing boom. These effects were amplified where innovations had increased the spendability of housing collateral (e.g., the US and UK). Although consumer spending was less directly affected by house price swings in other countries where housing collateral was less liquid, economic growth has declined from the global spill-over effects of the housing bust and any domestic slowing of construction (e.g., Spain). These effects were exacerbated by the global rise in financial frictions that massively reduced liquidity and capital flows, and had more general macroeconomic effects.

\subsubsection{International Transmission Via Increased Global Financial Frictions}

The international transmission of financial woes was especially manifest in the large rise in worldwide liquidity risk premiums in 2008, which resulted from a general rise in risk aversion and the real estate losses of many globally-invested financial institutions. Risk aversion indices jumped across many financial markets in late 2008, partly reflecting counter-party and default risk from large real estate losses. Assessments of those losses have steadily risen from \$500 billion for US residential mortgages originally estimated by Greenlaw, Hatzius, Kashyap, and Shin (2008) to $\$ 630$ billion later that year by Hatzius (2008). More recent estimates of these losses, plus the damage from losses on other structured financial products and losses induced by the economic downturn, have risen with the IMF (2009, p. xv, executive summary) putting US asset losses as high as $\$ 2.7$ trillion and global asset losses as high as $\$ 4$ trillion. 
Reflecting mounting concerns about large capital losses, counterparty and liquidity risk premiums rose in many financial markets. For example, spreads of LIBOR over short-term government interest rates jumped in most major economies, first with the August 9, 2007 halt in redemptions at several subprime mortgage-exposed hedge funds and later in the Fall of 2008 when Lehman Brothers collapsed (Figure 10). But spreads also fell in response to efforts to bolster liquidity, notably including central banks providing more long-term discount lending options to banks in late 2007, and even more prominently in response to coordinated efforts to reduce counterparty risk in the interbank lending markets (e.g., the G-7 announcement of October 10, 2008). Reflecting similar crisis dates but somewhat different timing of central bank liquidity program announcements, commercial paper and mortgage spreads have behaved similarly to Libor spreads.

The co-movements of money market interest rate spreads also likely reflect the more global nature of large financial institutions. As Cetorelli and Goldberg (2009) show, the income of large banks has become more international in nature, likely reflecting increased cross-border lending and the impact of globalization on the earnings of bank borrowers. Despite the spillover of loan losses via international investing, national differences in regulations still mattered, suggesting that there may be (1) room for more coordination of bank regulations and (2) much that national regulators can learn from one another. For example, although post-1999 changes in house prices in Spain were sharper than in the US, the incidence of bank failures had initially been lower in Spain.

Three regulatory differences probably played a role. First, reflecting tighter explicit regulation, lending standards were apparently not weakened by as much in Spain. As argued above, the recent Spanish house price cycle is largely explained by demand factors-income 
growth, second-home purchases by foreigners and very rapid population growth. Nevertheless, there was likely some de facto easing of credit standards, via the use of upwardly biased home appraisals in calculating LTV ratios, as discussed above. Second, Spanish regulations promote the use of dynamic loan loss provision, under which banks are encouraged to appropriately post loan loss reserves before loans become non-performing. As a result, loan loss provisioning and any possible impact on bank regulatory capital positions are less pro-cyclical in Spain. In contrast, such forward-looking provisioning is effectively disallowed in the US, partly on grounds that it would give banks too much leeway to manipulate posted earnings. The procyclicality of bank regulation is relevant to many countries (Borio, Furfine, and Lowe, 2001). Third, before the recent crisis, Spain imposed consolidation rules requiring banks to have similar capital cushions for on- and off-balance sheet exposures, an approach recently adopted elsewhere. Nevertheless, the huge swings in housing demand and inventories of unsold houses in Spain still pose challenges. In particular, Spanish banks face the danger that developers may be unable to meet maturing land and development loans used to create unsold multi-family residential units. ${ }^{18}$

From a broader perspective, the financial and housing crisis has hit the global financial system with several shocks that are correlated in at least two ways. First, in terms of direct channels, the plunge in housing demand choked off construction in countries such as Ireland, Spain, and the US. It also reduced consumption in other nations where a housing-collateral channel was present. The falls in consumption and construction, in turn, impacted the trading partners of these countries. In this regard, the liberalization of household credit markets has been

\footnotetext{
${ }^{18}$ In reaction to owning unsold units from maturing developer loans, some Spanish banks have offered high LTV loans with long maturities and low interest rate margins to potential homeowners, loans which they will probably not be able to fund with covered bonds but will generate some income (Mulligan, 2009). Similarly, maturing land and development loans for financing commercial real estate construction pose problems for banks headquartered in
} 
very important. And second, via financial channels, the asset losses and associated increases in investor risk aversion have severely restricted the supply of credit from bank and nonbank sources and led to widespread asset price declines. In this regard, the fragility of many new structured financial products was under-appreciated, as were the accompanying increases in counter-party exposures and the systemic risk to the global financial system. The likelihood and macroeconomic impact of unusual systemic risk events have been too difficult to gauge using standard frameworks on a limited historical record.

\section{Conclusion}

The world is grappling with a deep recession and many policy actions have had to be quickly implemented for pragmatic reasons. Many countries have taken action to bolster the capital positions of their banks. Some have implemented stress-test based capital requirements, and/or imposed more regulations on riskier types of mortgages. ${ }^{19}$ Although such steps have been taken, there is widespread recognition that a careful and comprehensive reform of regulations is needed (Bernanke, 2009). In this sense, the current crisis provides an opportunity to design and forge a new financial architecture that will better meet the needs for growth and stability.

This study focuses on what housing research can tell us about the nature of the recent housing and financial crisis, and some of the important lessons that we can draw for the future. These include (1) the critical role of financial innovation, misaligned incentives and duration positions, global financial imbalances and leverage for fueling credit booms; (2) the importance of financial liberalization and credit conditions for consumption, housing demand, residential construction, house prices, and cross country differences in economic performance and monetary

several OECD nations as the drying-up of the commercial MBS market makes it difficult for developers to sell newly completed properties to potential buyers.

${ }^{19}$ For example, see the G-7 statement of October 2008 (reported in US Treasury, 2008), Bernanke (2009), and Board of Governors of the Federal Reserve System (2007). 
transmission; (3) the unintended consequences of credit- rather than housing supply-focused efforts in some countries to meet the housing needs of younger families; (4) the spillover effects of the housing bust to other countries via risk premiums in global financial markets and via the current account; and (5) the importance of prudential and forward-looking regulation to reduce the pro-cyclicality of regulations and financial accelerator effects on economic activity.

Because the degree of financial liberalization and the elasticity of housing supply vary across countries and over time, the extent of fluctuations in house prices and construction will also vary. The resulting differences in house price volatility have implications for the protection that housing collateral provides to lenders and the impact of that collateral on consumption. However, this does not necessarily imply that countries with more flexible housing supply are more stable in the face of major shifts in housing demand. Indeed, large swings in housing construction have had major macroeconomic effects in Ireland, Spain, and the US.

These factors are also relevant to the issue of balancing two opposing pressures when designing or reforming international financial regulations. On the one hand, the regulations need to be flexible enough to accommodate countries with different housing finance systems. On the other hand, there is the risk that insufficient consistency in regulation, not just insufficient national regulation, may allow systemic risks to arise in a world with integrated financial and goods markets, as the recent crisis has so painfully demonstrated. 


\section{References}

Abraham, J. and P. Hendershott, 1996, Bubbles in metropolitan housing markets, Journal of Housing Research 7, 191-207.

Acharya, V. V., Brenner, M., Engle, R., Lynch, A., Richardson, M., 2009, Derivatives: the ultimate financial innovation. In: Acharya, V. V. and M. Richardson (Eds.), Restoring financial stability: how to repair a broken system, Wiley.

Acharya, V. V. and P. Schnabl, 2009, How banks played the leverage game. In: Acharya, V. V. and M. Richardson (Eds.), Restoring financial stability: how to repair a broken system, Wiley.

Adrian, T., and H.S. Shin, forthcoming, Liquidity and leverage, Journal of Financial Intermediation.

Adrian, T., and H.S. Shin, 2008, Financial intermediary leverage and value at risk, Federal Reserve Bank of New York Staff Reports, 338.

Ahearn, A. G., Ammer, J. , Doyle, B.M., Kole, L.S., and R.F. Martin, 2005, House prices and monetary policy: a cross-country study, International Finance Discussion Paper No. 841, Board of Governors of the Federal Reserve System.

Aoki, K., Proudman, J., and Vlieghe, G. 2004, House prices, consumption, and monetary policy: a financial accelerator approach, Journal of Financial Intermediation 13, 414-435.

Aron, J., Muellbauer, J. and Murphy, A. 2006, Housing wealth and UK consumption, Economic Outlook, 30 (4), 11-20.

Aron, J., Duca, J., Muellbauer, J., Murata, K., Murphy, A., 2009, Credit, housing collateral and consumption in the UK, U.S., and Japan, mimeo.

Barker, K. 2003, Review of housing supply: interim report-analysis, London, HM Treasury. 
Barker, K., 2004, Review of housing supply - final report, London, HM Treasury.

Bennett, P., Peach, R., Peristiani, S., 2001, Structural change in the mortgage market and the propensity to refinance, Journal of Money, Credit, and Banking 33 (4), 955-75.

Bernanke, B. S., 2009, Lessons of the financial crisis for banking supervision, speech to the 2009 Federal Reserve Bank of Chicago Conference on Bank Structure and Competition, Chicago, IL, U.S.A., May 7, 2008, http://www.federalreserve.gov/newsevents/speech/bernanke20090507a.htm .

Blake, N., Muellbauer, J., 2009, Developing analytical methods for the identification of imbalance and risks in the EU housing markets, Report to the European Commission, September.

Blanchard, O., Katz, L., 1992, Regional evolutions, Brookings Papers on Economic Activity 1992(1), 1-76.

Board of Governors of the Federal Reserve System, 2007, Statement on subprime mortgage lending, June 2007, http://www.federalreserve.gov/newsevents/press/bcreg/bcreg20070629a1.pdf .

Borio, C., Furfine, C., Lowe, P., 2001, Procyclicality of the financial system and financial stability: issues and policy options, BIS papers, no. 1.

Bover, O., 2007, Wealth effects on consumption: microeconometric estimates from a new survey of household finances, Banco de España working paper 0522.

Bramley, G., 1993a, The impact of land-use planning and tax subsidies on the supply and price of housing in Britain, Urban Studies 30, 5-30.

Bramley, G., 1993b, Land-use planning and the housing market in Britain—-the impact on house building and house prices, Environment and Planning A, 25, 1021-51. 
Bramley, G., Leishman, C., 2005, A local housing market model with spatial interaction and land-use planning controls, Environment and Planning A, 37 (9), 1637-49.

Brayton, F., Tinsley, P., 1996, A guide to FRB/US: a macroeconomic model of the United States, FEDS working paper 1996-42, Board of Governors of the Federal Reserve System.

Browning, M., Gortz, M., and S. Leth-Petersen, 2008, House prices and consumption: a micro study, mimeo, Nuffield College, Oxford University.

The Brunei Times, 2008, Debt forces migrants to default and return home, October 3, 2008.

Buiter, W., 2008, Housing wealth isn't wealth, NBER working paper no. 14204.

Calomiris, C. W. and P.J. Wallison, 2008, The last trillion dollar commitment: the destruction of Fannie Mae and Freddie Mac, AEI Financial Services Outlook, September 30, 2008, $<\underline{\text { http://www.aei.org/publications/pubID.28704/pub_detail.asp }>}$

Cameron, G., Muellbauer, J. and Murphy, A., 2006, Was there a british house price bubble? evidence from a regional panel, CEPR discussion paper no. 5619.

Campbell, J. Y., and Cocco, J., 2007, How do house prices affect consumption? Evidence from micro data, Journal of Monetary Economics 54, 591-621.

Canner, G., Dynan, K. and Passmore, W., 2002, Mortgage refinancing in 2001 and early 2002, Federal Reserve Bulletin 88, 469-81.

Capozza, D., Seguin, P. 1996, Expectations, efficiency, and euphoria in the housing market, Regional Science and Urban Economics 26, 369-86.

Carroll, C., Kimball, M., 2004, Liquidity constraints and precautionary saving, mimeo, Johns Hopkins University. 
Carroll, C., Otsuka, M., Slacalek, J., 2006, How large Is the housing wealth effect? A new approach, mimeo, Johns Hopkins University.

Case, K.E., Quigley, J.M, 2008, How housing booms unwind: income effects, wealth effects, and feedbacks through financial markets, European Journal of Housing Policy 8 (2), 161-180.

Case, K., Quigley, J., Shiller, R., 2005, Comparing wealth effects: the stock market versus the housing market, Advances in Macroeconomics, 5 (1), Article 1. Online at http://www.bepress.com/bejm/advances/vol5/iss1/art1.

Case, K. E. and R. J. Shiller, 1988, The behavior of home buyers in boom and post-boom markets, New England Economic Review, Federal Reserve Bank of Boston, November/ December, 29-46.

Case, K. E. and R. J. Shiller, 1989, The efficiency of the market for single-family homes, American Economic Review 79, 125-37.

Case, K. E. and R. J. Shiller, 1990, Forecasting prices and excess returns in the housing market, Journal of the American Real Estate and Urban Economics Association 1990, 18, 253-73.

Catte, P., Girouard, N., Price, R., Andre, C., 2004, Housing markets, wealth and the business cycle, OECD Economics Department Working Papers, No. 394, OECD Publishing.

Cetorelli, N., Goldberg, L., 2009, Banking globalization and monetary transmission, mimeo, Federal Reserve Bank of New York.

Chiuri, M., Jappelli, T., 2003, Financial market imperfections and home ownership: a comparative study, European Economic Review 47, 857-875.

Clayton, J., 1996, Rational expectations, market fundamentals and housing price volatility, Real Estate Economics 24, 441-70. 
Clayton, J. 1997, Are housing price cycles driven by irrational expectations? Journal of Real Estate Finance and Economics 14, 341-63.

Cooper, D. 2009, Impending spending bust? The role of housing wealth as borrowing collateral, mimeo, University of Michigan.

Corden, W.M., 2009, China's exchange rate policy, its current account surplus and the global imbalances, The Economic Journal 119, F430-F441.

Cortina, A., 2009, The residential boom and its consequences: a view from a Spanish bank, presentation at the SUERF/Bank of Finland conference: "Housing Markets: A Shelter From the Storm or a Cause of the Storm?” June.

Credit Suisse, 2007, Mortgage quality du jour: underestimated no more, March 13, 2007.

Cunningham, C. R., Englehardt, G.V., forthcoming, Housing capital-gains taxation and homeowner mobility: evidence from the taxpayer relief act of 1997, Journal of Urban Economics,

Davis, M. A ., Heathcote, J., 2005, The price and quantity of residential land in the United States, International Economic Review 46, 751-84.

Davey, M., 2001, Mortgage equity withdrawal and consumption, Bank of England Quarterly Bulletin, Spring, 1001-03.

Deng, Y. Quigley, J., Van Order, R., 2000, Mortgage terminations, heterogeneity and the exercise of mortgage options, Econometrica 68 (2), 275-307.

DiMartino, D., .Duca, J.V., 2007, The rise and fall of subprime mortgages, Federal Reserve Bank of Dallas Economic Letter, November, $<\underline{\text { http://dallasfed.org/research/eclett/2007/el0711.pdf }>}$

DiMartino, D., Duca, J. V., Rosenblum, H. 2007, From complacency to crisis: financial risk- 
taking in the early $21^{\text {st }}$ century, Federal Reserve Bank of Dallas Economic Letter, December, < $\underline{\text { http://dallasfed.org/research/eclett/2007/el0712.pdf> }}$

DiPasquale, D., 1999, What don’t we know about housing supply? Journal of Real Estate Finance and Economics 18, 9-25.

Doms, M., Krainer, J., 2007, Innovations in mortgage markets and increased spending on housing, Federal Reserve Bank of San Francisco working paper no. 05.

Duca, J.V., 1996, Deposit deregulation and the sensitivity of housing, Journal of Housing Economics 5, 207-27.

Duca, J.V., DiMartino, D., Renier, J., 2009, Fed confronts financial crisis by expanding its role as lender of last resort, Federal Reserve Bank of Dallas Economic Letter, February/March 2009. <http://dallasfed.org/research/eclett/2009/el0902.pdf>

Duca, J.V., 2006a, Making sense of the U.S. housing slowdown, Federal Reserve Bank of Dallas Economic Letter, November. <http://dallasfed.org/research/eclett/2006/el0611.pdf>

Duca, J.V., 2006b, Mutual funds and the evolving long-run effects of stock wealth on U.S. consumption, The Journal of Economics and Business 58, 202-221.

Duca, J.V., Johnson, K.B., Muellbauer, J. 2009, Time series estimates of U.S. mortgage constraints and regional home supply, mimeo, Oxford University.Duca, J.V., Muellbauer, J., and Murphy, A., 2009a, Credit constraints and house prices: making sense of the U.S. experience, mimeo, Oxford University.

Duca, J.V., Muellbauer, J., Murphy, A., 2009b, The financial crisis and consumption, mimeo, Oxford University.

The Economist 2007, The trouble with the housing market, print edition, March 22, 2007.

Englehardt, G. V., 1996, House prices and home owner saving behavior, Regional Science 
and Urban Economics 26, 313-336.

Engelhardt, G.V., 1996, Consumption, down payments and liquidity constraints, Journal of Money Credit and Banking 28 (2), 255-71.

Englund, P., 2003, Taxing residential housing capital, Urban Studies 40, 937-952.

European Central Bank, 2003, Structural Factors in the EU housing markets, March.

European Central Bank, 2009, Housing finance in the Euro area, Task force of the monetary policy committee of the European system of central banks, Occassional paper no. 101.

Evans, A.W., 1996, The impact of land-use planning and tax subsidies on the supply and price of housing in Britain, Urban Studies, 33, 581-85.

Fernandez-Corregudo, E., Muellbauer, J. 2006, Consumer credit conditions in the U.K., Bank of England working paper 314.

Foote, C.L., Gerardi, K., Willen, P.S., 2008, Negative equity and foreclosure: theory and evidence, Journal of Urban Economics 64, 234-245.

Foote, C.L., Fuhrer, J., Mauskopf, E., Willen, P.S., 2009, A proposal to help distressed homeowners: a government payment-sharing plan, Federal Reserve Bank of Boston, February 10, http://www.bos.frb.org/economic/paymentsharingproposal.pdf .

Fortune, C., Moohan, J. 2008, International variations in new housing supply, Journal of Housing Markets and Analysis 2008 1(4), 379-92.

Frame, W.S., 2008, The 2008 federal intervention to stabilize Fannie Mae and Freddie Mac, Journal of Applied Finance 18 (2), 124-36.

Gerardi, K., Lehnert, A., Sherlund, S.M., Willen, P.S., 2008, Making sense of the subprime crisis, Brookings Papers on Economic Activity 2008 (2), 69-145. 
Girouard, N., Blondal, S., 2001, House prices and economic activity, OECD Economics Department working papers, no. 279.

Girouard, N., Kennedy, M., van den Nord, P., Andre, C., 2006, Recent house price developments, OECD Economics Department working papers, no. 475.

Goodman, J. L. Ittner, J.B., 1992, The accuracy of home owners' estimates of house value, Journal of Housing Economics 2 (4), 339-357.

Grant, C., Peltonen, T., 2004, Income and wealth effects of italian households, mimeo, European University Institute.

Green, R., Wachter, S., 2007, The housing finance revolution, In: Housing, housing finance, and monetary policy, A Symposium Sponsored by the Federal Reserve Bank of Kansas City, Jackson Hole, Wyoming, August 30 - September 1, 2007, 21-67.

Greenlaw, D., Hatzius, J, Kashyap, A., Shin, H., 2008, Leveraged losses: lessons from the mortgage market meltdown, Proceedings of the U.S. Monetary Policy Forum 2008.

Greenspan, A., Kennedy, J., 2008, Sources and uses of equity extracted from homes, Oxford Review of Economic Policy 24 (1), 120-44.

Hamilton, B., Schwab, R., 1985, Expected appreciation in urban housing markets, Journal of Urban Economics 18, 103-18.

Hendershott., P.H., 1992, Are real house prices likely to decline by 47 percent? Regional Science and Urban Economics, 22: 553-563.

Himmelberg, C., Mayer, C., Sinai, T., 2005, Assessing high house prices: bubbles, fundamentals, and misperceptions, Journal of Economic Perspectives 19, Winter, 67-92.

Hurst, E., Stafford, F., 2004, Home is where the equity is: mortgage refinancing and household consumption, Journal of Money, Credit, and Banking 36 (6), 985-1014. 
IMF, 2006, Spain: financial sector assessment program—technical note-

housing prices, household debt, and financial stability, IMF country report no. 06/210, $<$ http://internationalmonetaryfund.com/external/pubs/ft/scr/2006/cr06210.pdf $>$.

IMF, 2009, Global financial stability report: responding to the financial crisis and measuring systemic risks, April 2009. http://www.imf.org/external/pubs/ft/gfsr/2009/01/index.htm

Jaffee, D.M., 2003, The interest rate risk of Fannie Mae and Freddie Mac, Journal of Financial Services Research 24 (1), 5-29.

Jaffee, D.M. 2009, The U.S. subprime crisis: issues raised and lessons learned. In: Urbanization and Growth, Spence, M., Annez, P., Buckley, R.M., (Eds.), The World Bank.

Juster, F.T., Lupton, J.P., Smith, J.P., Stafford, F., 2005, The decline in household saving and the wealth effect, Review of Economics and Statistics 87 (4), 20-27.

Kau, J.B., Keenan, D.C., Muller, W.J., Epperson, J. F., 1992, A generalized valuation model for fixed-rate residential mortgages, Journal of Money, Credit and Banking 24 (3), 279-99.

Kennedy, N., Andersen, P., 1994. Household saving and real house prices: an international perspective, Bank for International Settlements working paper, no. 21.

Kim, Y., 2007, Rent-price ratios and the earnings yield on housing, mimeo, University of Southern California, $<\underline{\text { http://www- }<\text { rcf.usc.edu/ yongkim/housingyield1007.pdf }>}$

Kindleberger, C. P., Aliber, R., 2005, Manias, panics, and crashes: a history of financial crises, $5^{\text {th }}$ edition, John Wiley and Sons.

Labaton, S., 2008, The reckoning: agency’s 2004 ruling let banks pile up debt, The New York 
Times (October 2), < http://www.nytimes.com/2008/10/03/business/03sec.html>.

Leamer, E.E., 2007, Housing is the business cycle, In: Housing, housing finance, and monetary policy, A Symposium Sponsored by the Federal Reserve Bank of Kansas City, Jackson Hole, Wyoming, August 30 - September 1, 2007, 149-233.

Ludwig, A., Slok, T., 2002, The impact of changes in stock prices and house prices on consumption in OECD countries, IMF working paper no. 1.

MacLennan, D., Muellbauer, J., Stephens, M., 1998, Asymmetries in housing and financial market institutions and EMU, Oxford Review of Economic Policy 14 (3), 54-80.

Malpezzi, S., Maclennan, D., 2001, The long-run price elasticity of supply of new residential construction in the United States and the United Kingdom, Journal of Housing Economics, 10 (3), 278-306.

Mankiw, N.G., Weil, D., 1989, The baby boom, the baby bust, and the housing market, Regional Science and Urban Economics 19, 235-58.

Mayer, C. J., Somerville, C.T., 2000a, Residential construction: using the urban growth model to estimate housing supply', Journal of Urban Economics 48 (1), 85-109.

Mayer, C. J., Somerville, C.T., 2000b, Land use regulation and new construction, Regional Science and Urban Economics 30 (6), 639-62.

Mayer, C., Pence, K., Sherlund, S.M., 2009, The rise in mortgage defaults, Journal of Economic Perspectives 23, Winter, 27-50.

Mayo, S., Sheppard, S., 1991, Housing supply and the effects of stochastic development control, Oberlin discussion paper in economics, Oberlin University.

Mayo, S., Sheppard, S., 1996, Housing supply under rapid economic growth and varying 
regulatory stringency: an international comparison, Journal of Housing Economics, 5 (3), 274-89.

Meeks, R., 2008, Financial crisis casts shadow over commercial real estate, Federal Reserve Bank of Dallas Economic Letter, December, < http://dallasfed.org/research/eclett/2008/el0812.pdf $>$

Meen, G., 2001, Modeling Spatial housing markets: theory, analysis, and policy, Kluwer Academic Publishers, 2001.

Meese, R., Wallace, N. 1994, Testing the present value relation for housing prices: should I leave my house in San Francisco? Journal of Urban Economics 35, 245-66.

Miles, D., 1997, A household level study of the determinants of incomes and consumption, Economic Journal 107, 1-25.

Miles, D., 1992, Housing markets, consumption, and financial liberalization, European Economic Review 36, 1093-1136.

Muellbauer, J. 2009, Household decisions, credit markets and the macroeconomy: implications for the design of central bank models, mimeo, Bank for International Settlements’ 2009 Annual Meeting, June.

Muellbauer, J., 2007, Housing, credit and consumer expenditure. In: Housing, housing finance, and monetary policy, A Symposium Sponsored by the Federal Reserve Bank of Kansas City, Jackson Hole, Wyoming, August 30 - September 1, 2007, 267-334.

Muellbauer, J., Lattimore, R., 1995, The consumption function: a theoretical and empirical overview, in Pesaran, H., Wickens, M. (Eds.), Handbook of Applied Econometrics, Blackwell. 
Muellbauer, J., Murata, K., 2008, Consumption, consumption, land prices and the monetary transmission mechanism in Japan, mimeo, Oxford University

Muellbauer, J., Murphy, A. 1997, Booms and busts in the U.K. housing market, The Economic Journal 107, 1701-27.

Muellbauer, J., Murphy, A. 1990, Is the UK balance of payments sustainable? Economic Policy 11, 347-95.

Muellbauer, J., Murphy, A., 2008, Housing markets and the economy: the assessment, Oxford Review of Economic Policy, 24 (1), 1-33.

Muellbauer, J. and Williams, D., 2010, The elephant in the room: The impact of credit conditions on Australian house prices, mortgage lending, equity withdrawal and Consumption, mimeo, Oxford University.

Mulligan, M., 2009, After the bubble comes the overhang, The Financial Times, Special Report on Spain, June 10, 3.

Murata, K., 1999, The consumption function in Japan, DPhil thesis, Oxford University.

Murphy, A., 2006, Explaining Irish house prices: a review and some new results, mimeo, Oxford University.

Paiella, M., 2007, Does wealth affect consumption? evidence for Italy, Journal of Macroeconomics, 29 (1), 189-205.

Peek, J., 1983, Capital gains and personal saving behavior, Journal of Money, Credit and Banking, 15, 1-23.

Piazzesi, M., Schneider, M., 2009, Momentum traders in the housing market: survey evidence and a search model, National Bureau of Economic Research working paper no. 14669.

Poterba, J., 1990, Do taxes matter? In Slemrod, J. (Ed.), The impact of the Tax Reform Act of 1986, 141-60, MIT Press. 
Poterba, J. 1991, House price dynamics: the role of tax policy and demography, Brookings Papers on Economic Activity 22 (2), 143-203.

Quigley, J. M., 2007, Regulation and property values in the United States: the high cost of monopoly, in Ingram, G. K., Yu-Hung, H. (eds), Land policies and their outcomes, Cambridge, MA, Lincoln Institute, 46-66.

Rajan U., Seru, A., Vig, V. 2008, The failure of models that predict failure: distance, incentives and defaults, Chicago GSB Research Paper No. 08-19.

Saiz, A., 2008, On local housing supply elasticity, Wharton School, University of Pennsylvania, mimeo.

Scheinkman, J.A., Xiong, W., 2003. Overconfidence and speculative bubbles, Journal of Political Economy 111(6), 1183-219.

Sherlund, S.M., 2008, The past, present, and future of subprime mortgages, Board of Governors of the Federal Reserve System, FEDS working paper 2008-63.

Slacalek, J. 2009, What drives personal consumption? The role of housing and financial wealth, The B.E. Journal of Macroeconomics, Berkeley Electronic Press, vol. 9(1), 1-35.

Skinner, J., 1989, Housing wealth and aggregate consumption, Regional Science and Urban Economics 19, 305-324.

Skinner, J., 1994, Housing and saving in the United States. In Noguchi, Y., Poterba,„J. (Eds.), Housing markets in the United States and Japan, Chicago University Press for NBER, $191-214$.

Skinner, J., 1996, Is housing wealth a sideshow? In Wise, D. (Ed.), Papers in the economics of aging. University of Chicago Press. 
Smith, M.H., Smith, G. 2006, Bubble, bubble, where's the housing bubble? Brookings Papers on Economic Activity 37 (1), 1-68.

Swank, J., Kakes, J., Tieman, A.F. 2002, The housing ladder, taxation and borrowing constraints, DNB Report No. 9, Amsterdam.

Theil, H., 1976, Theory and measurement of consumer demand, studies in mathematical and managerial economics 21, North-Holland.

Tilton, A., 2007, Goldman Sachs, US Economics Analyst, February 23.

Titman, S., 1985, Urban land prices under uncertainty, American Economic Review 75, 505-14.

U.S. Treasury, 2008, G-7 finance ministers and central bankers plan of action, October 10, 2008, Washington, D.C., USA, http://www.treas.gov/press/releases/hp1195.htm .

Vandell, K.D., 1995, How ruthless is mortgage default? A review and synthesis of the evidence, Journal of Housing Research 6 (2), 245-264.

Vermeulen, W., Rowendal, J., 2007, Housing supply and land use regulation in the Netherlands, Tinbergen Institute Discussion Paper, TI 2007-058/3.

Vitner, M., Iqbal, A. 2009, What drives consumer delinquency rates? Wachovia Economics Group Special Commentary, June 18, http://www.fxstreet.com/fundamental/analysisreports/special-commentary/2009-06-19.html.

Williams, D.M., 2009, House prices and financial liberalization in Australia, mimeo, Oxford University, May. 


\section{Figure 1: U.S. Mortgage Financial Flows, 2000-06}

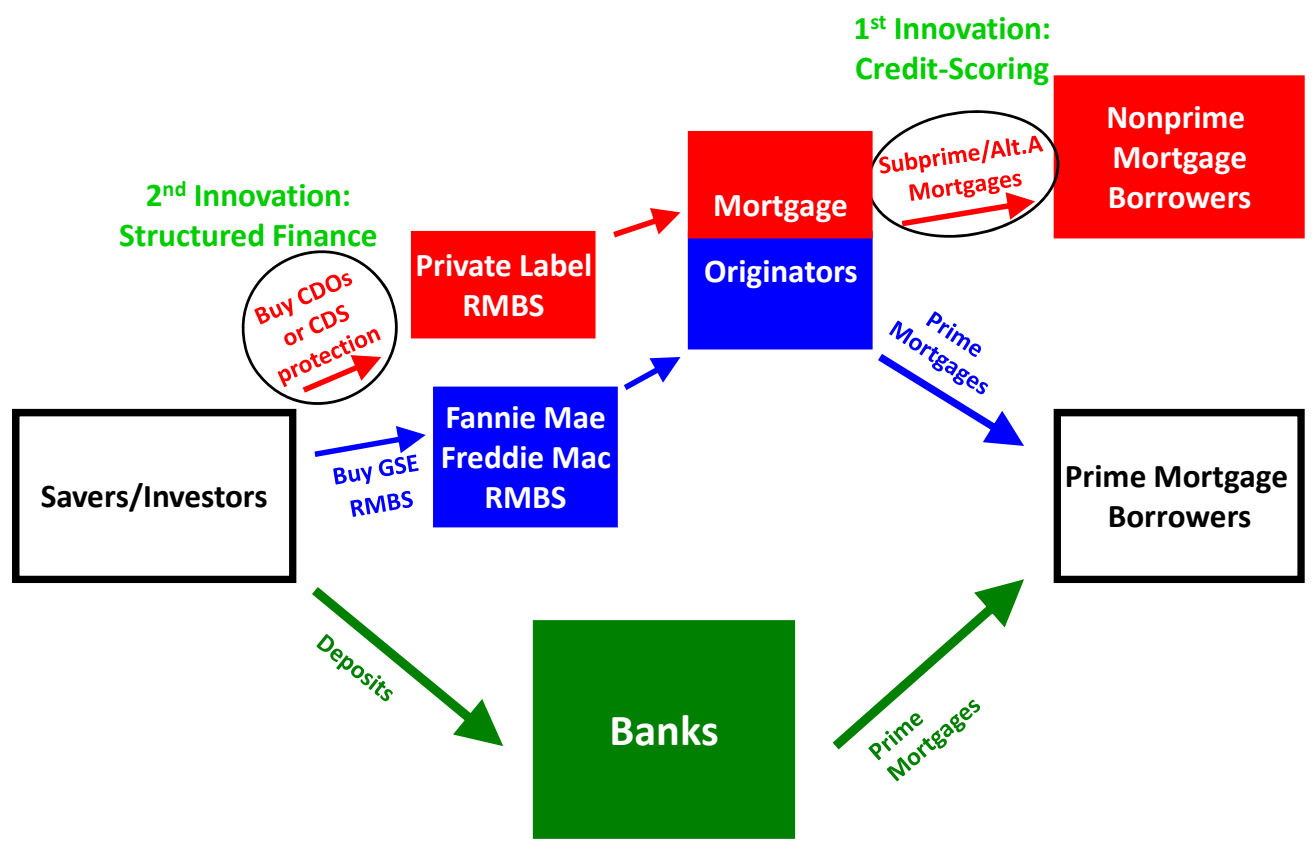

Figure 2: Unexpected Subprime Losses Undermined Highly “Rated" CDO Tranches
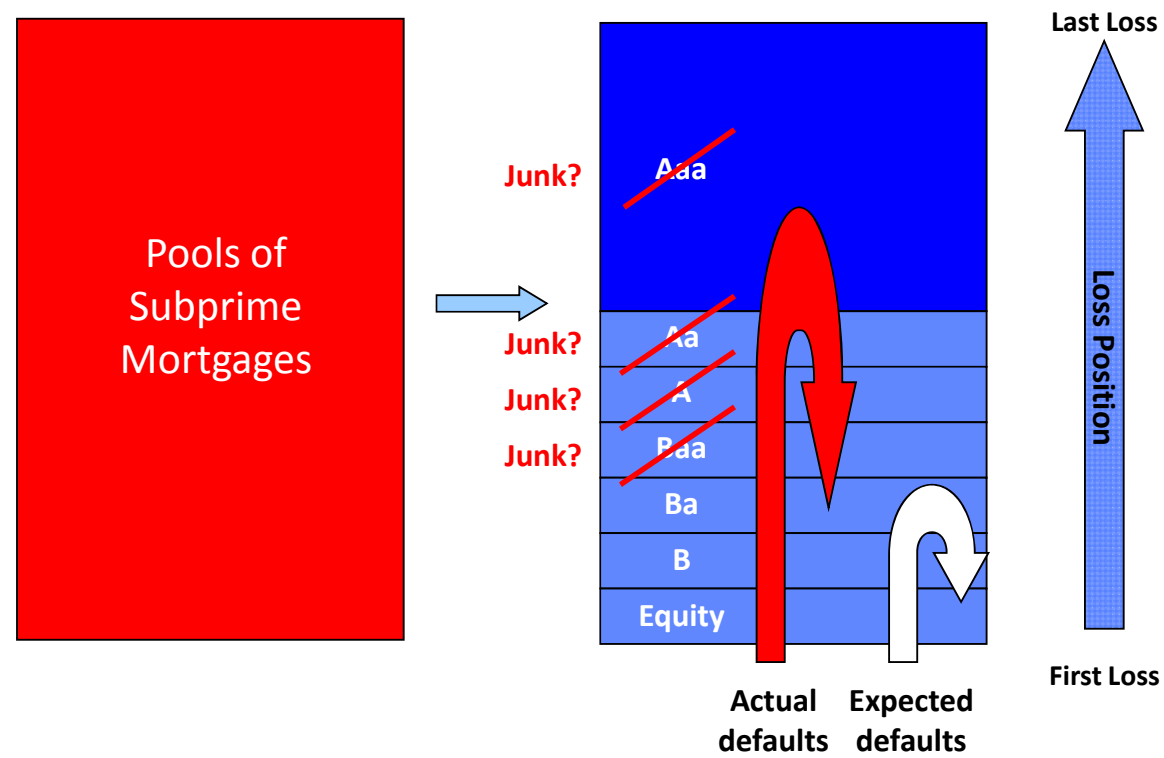

Source: author modified from Commercial Mortgage Securities Association. 


\section{Figure 3: Problem Mortgages Surge Beyond What Job Growth Alone Suggested}

SA, percent

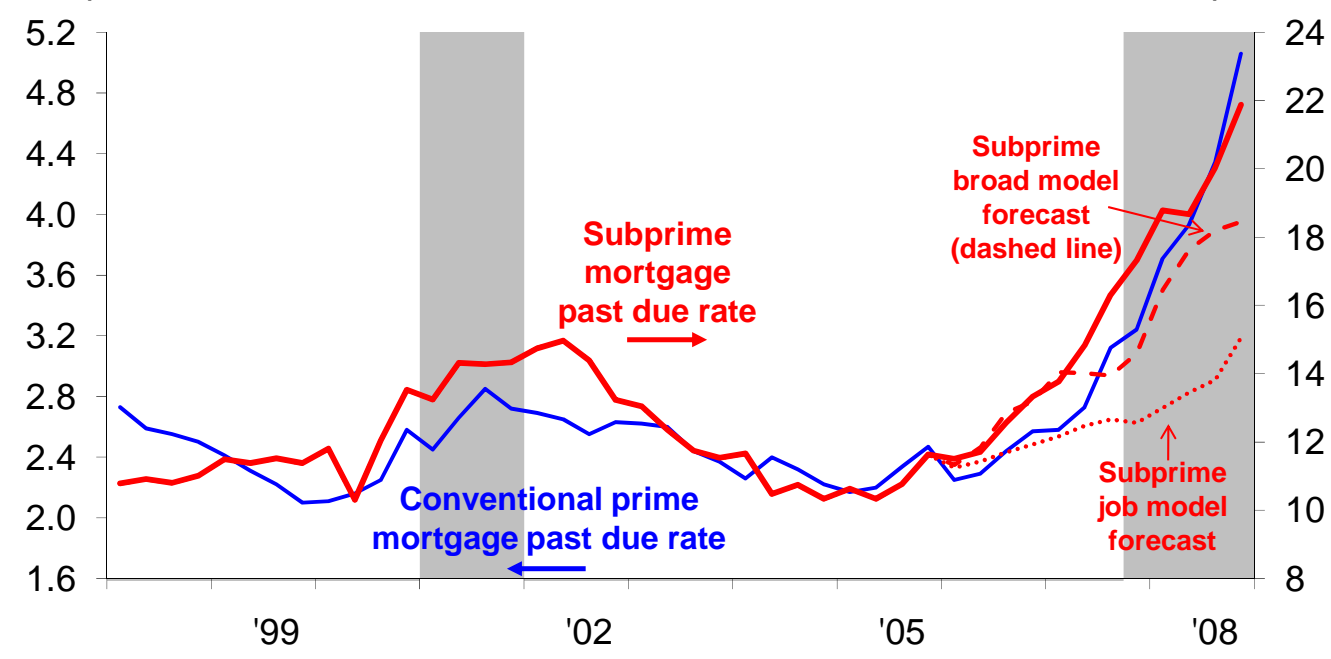

Source: Mortgage Bankers Association and authors' calculations.
SA, percent

24

22

20

18

16

14

12

10

8

Figure 4: U.S. Consumption \& Housing Boom Largely Financed by Current Account?

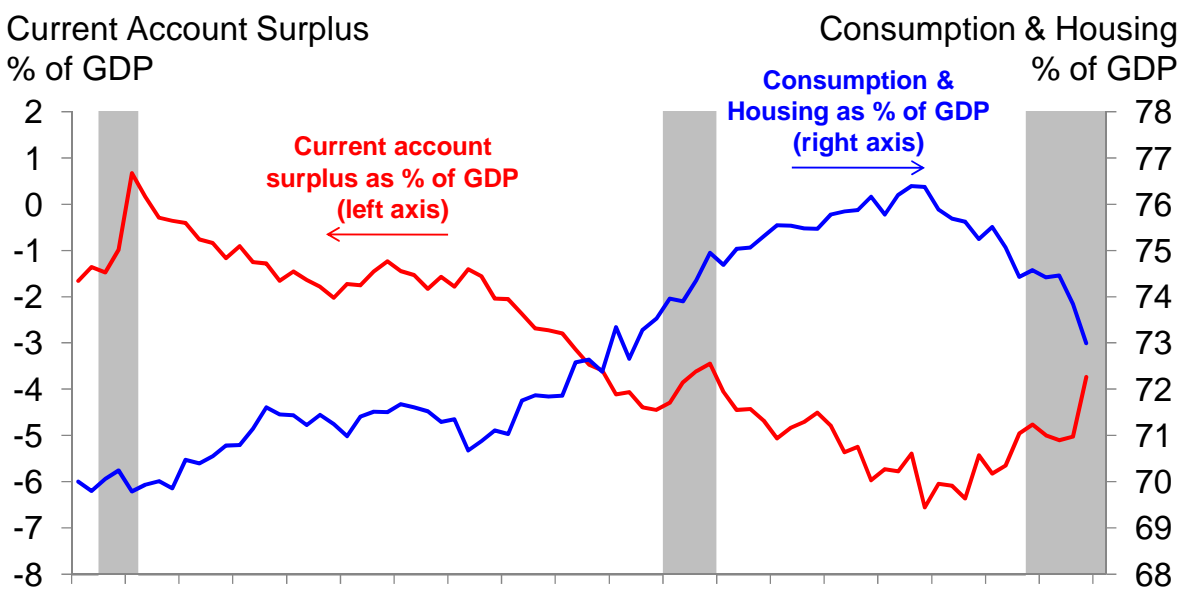

'90 '91 '92 '93 '94 '95 '96 '97 '98 '99 '00 '01 '02 '03 '04 '05 '06 '

Source: U.S. Bureau of Economic Analysis and authors' calculations. 
Figure 5: House Price-to-Rent Ratios Vary Across Supply

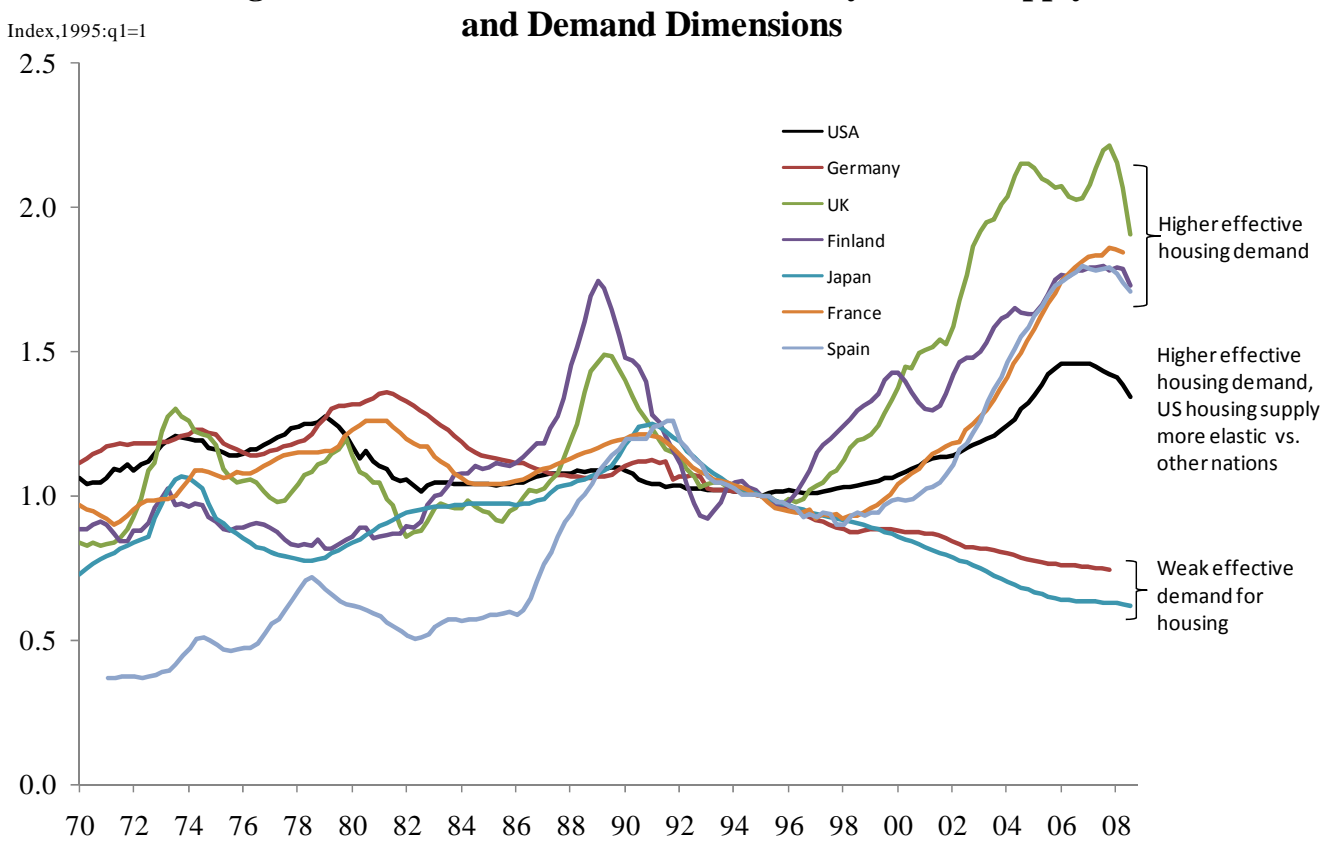

Source: Authors' rebasing of the OECD data set of Girouard et al. (2006).

Fig. 6: House Price-to-Rent Ratios Rise After Mortgage Terms Eased

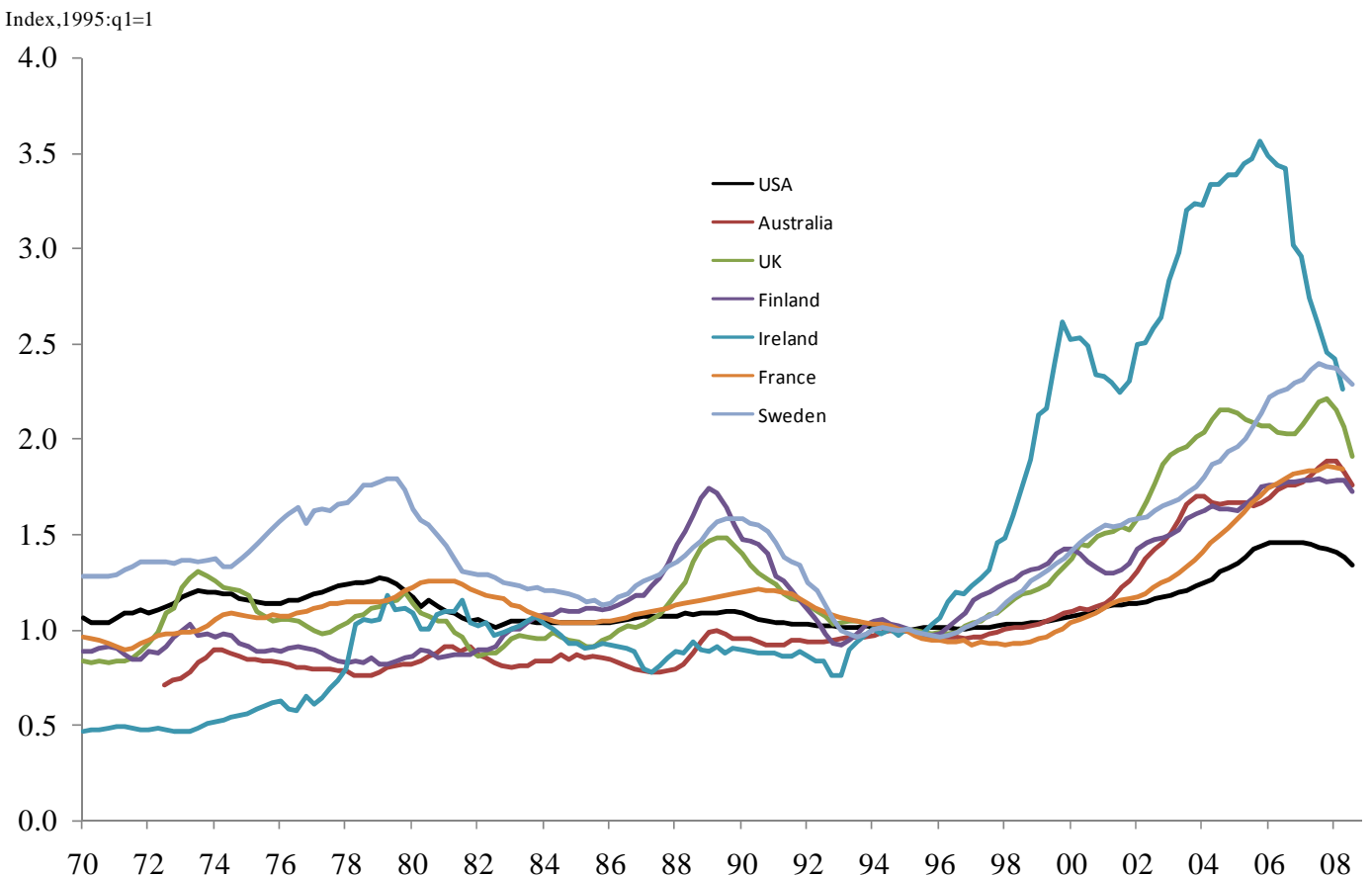

Source: Authors' rebasing of the OECD data set of Girouard et al. (2006). 


\section{Figure 7: Timing of House Price-To-Rent Booms Differs}

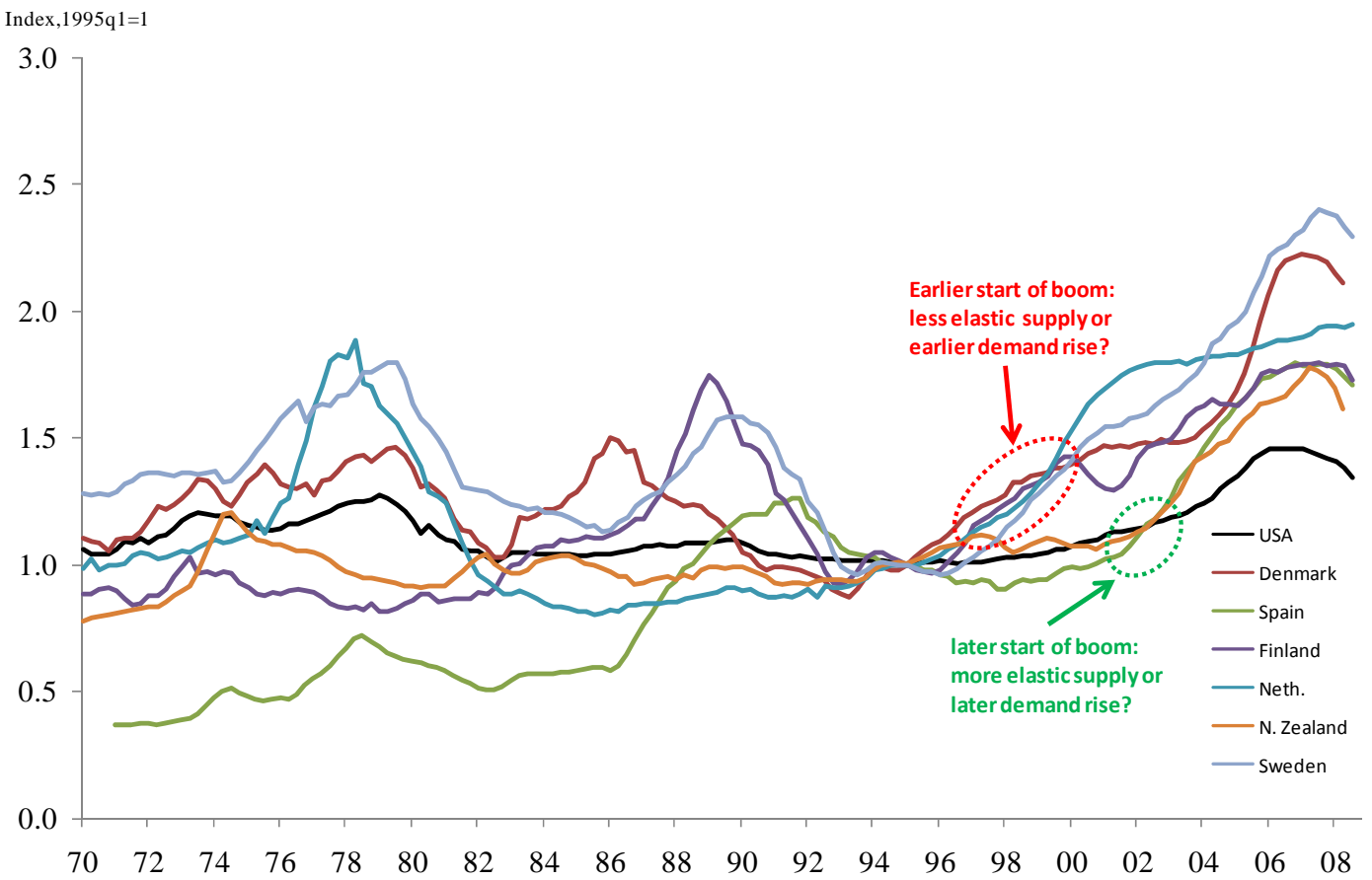

Source: Authors' rebasing of the OECD data set of Girouard et al. (2006).

Figure 8: Residential Construction Share of GDP Drops in Ireland, Spain, and the U.S.

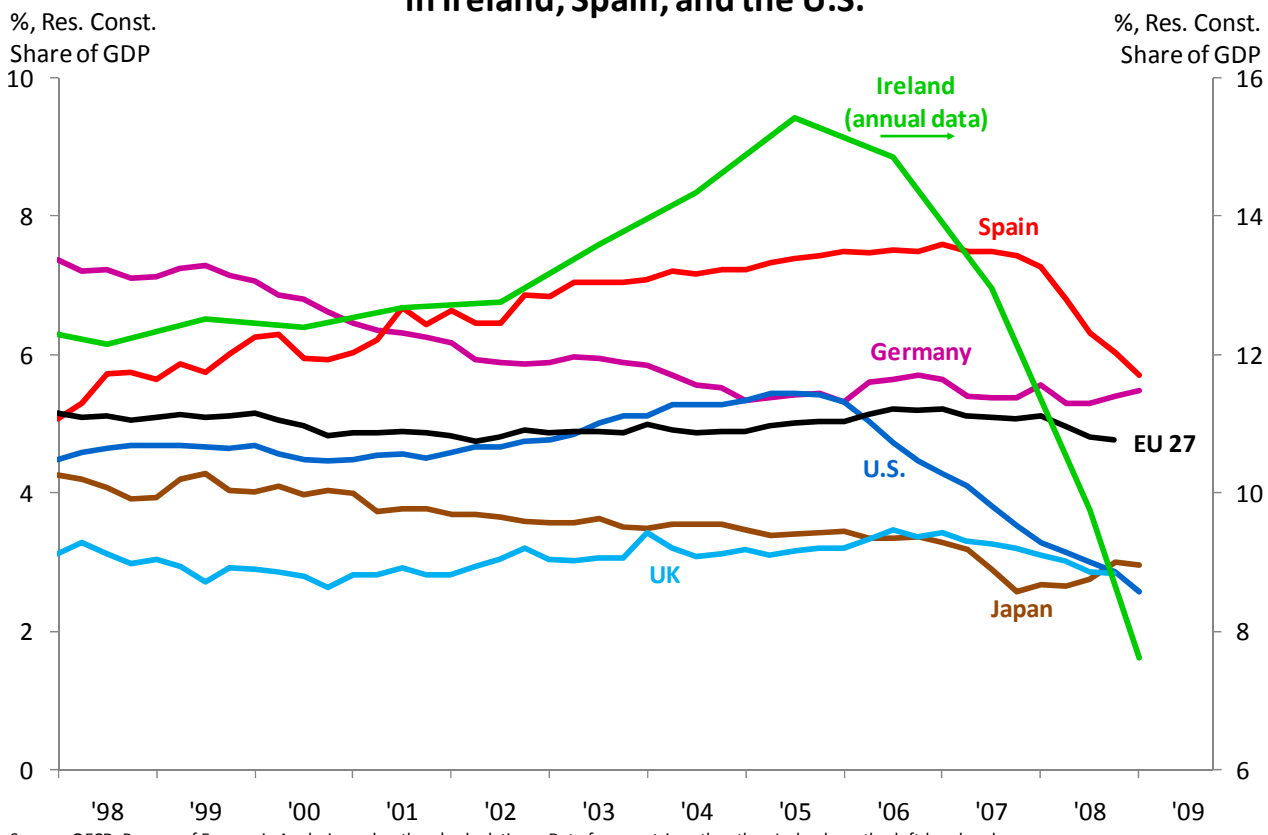

Source: OECD, Bureau of Economic Analysis, and authors' calculations, Data for countries other than Ireland use the left-hand scale. 
Figure 9: Financial and Tax Innovations Linked to Changes in MEW Sensivity to Swings in Real House Price Appreciation

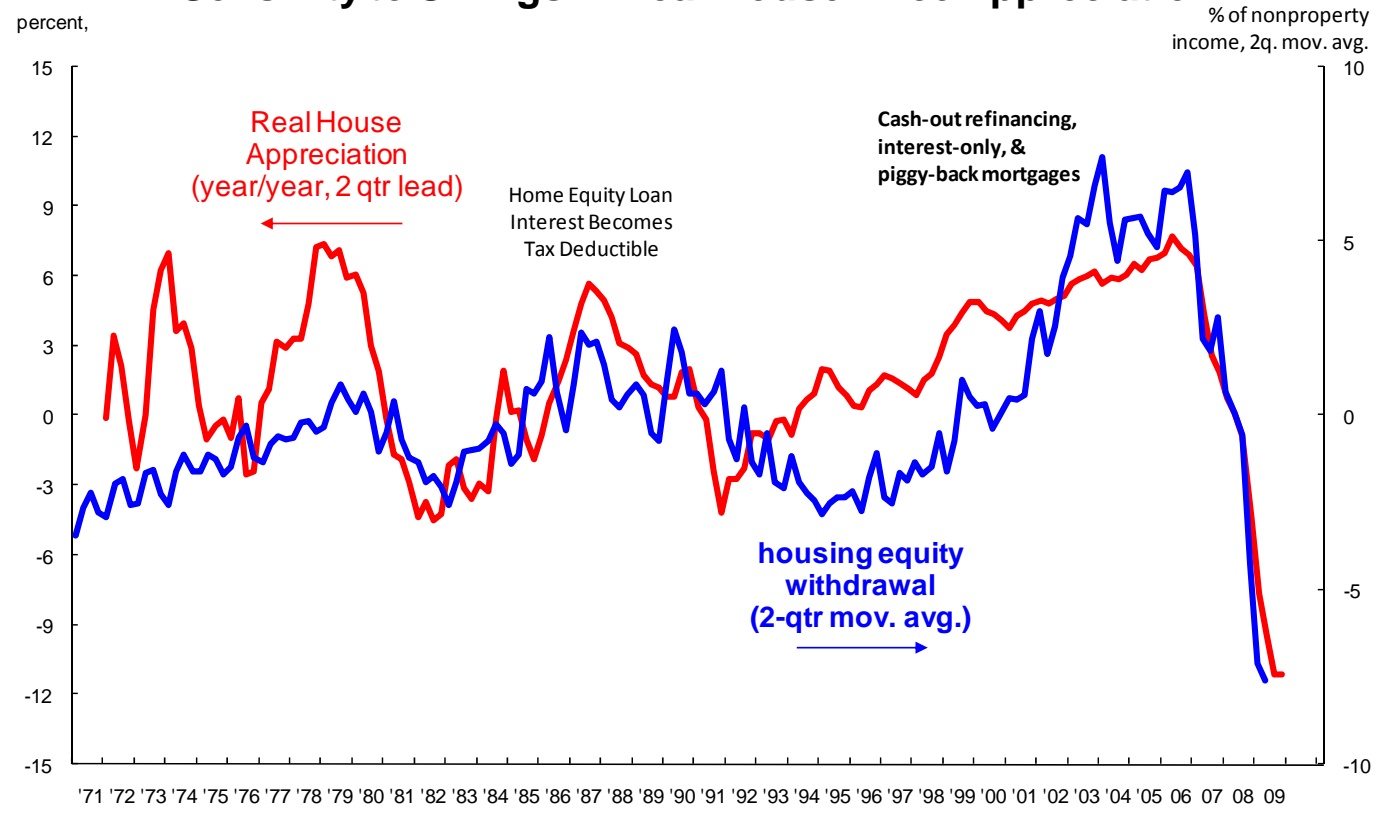

Figure 10: 3-Month LIBOR/OIS Spreads Retreat From Post-Lehman Highs

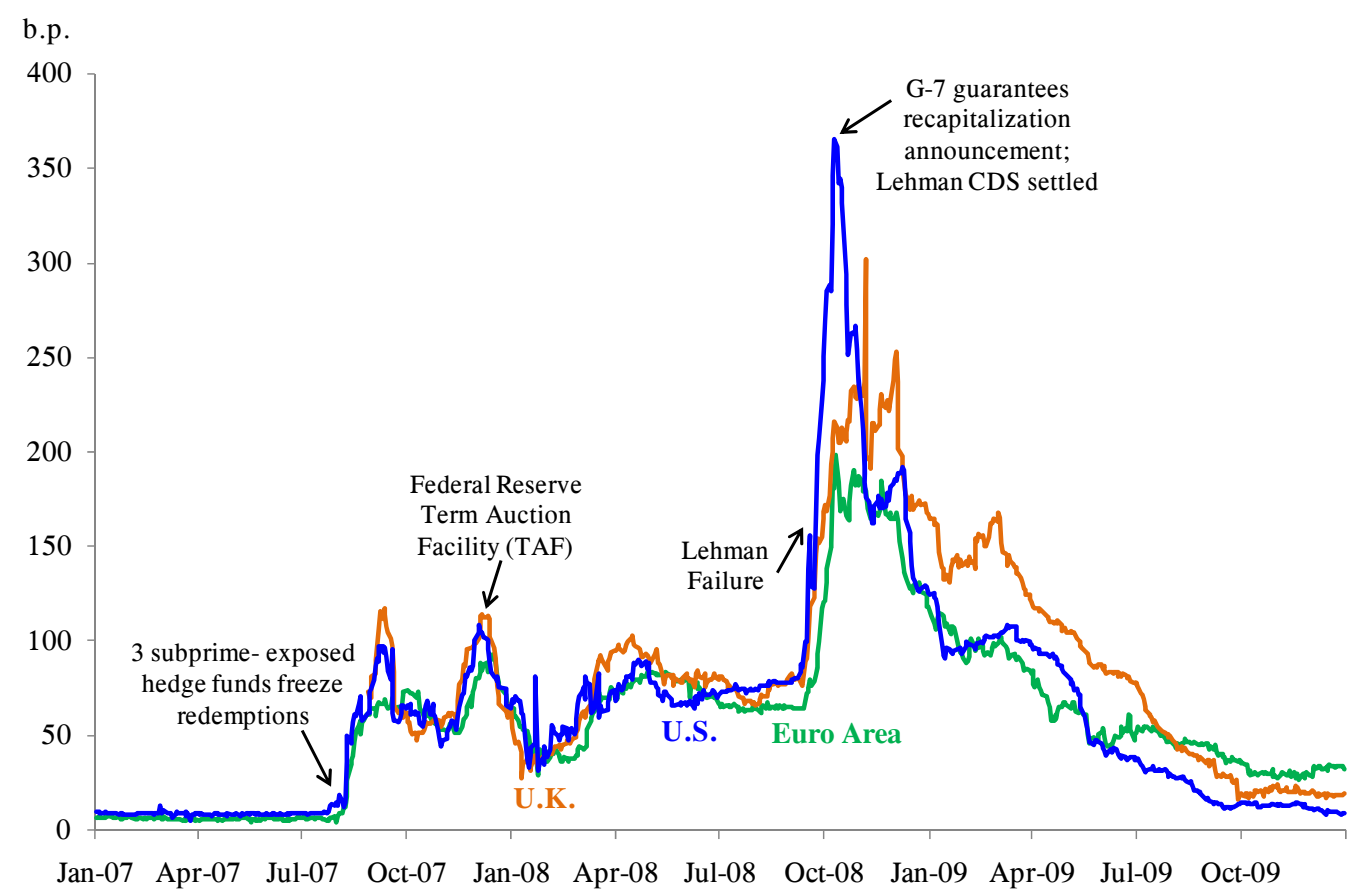


Table 1: Drivers of House Prices and Construction During the 2000-2009 Decade

\begin{tabular}{|c|c|c|c|c|c|}
\hline Country & $\begin{array}{l}\text { Housing } \\
\text { Supply } \\
\text { Elasticity }^{1}\end{array}$ & $\begin{array}{l}\text { Standard Housing } \\
\text { Demand Factors, } \\
\text { Notable cycle? }\end{array}$ & $\begin{array}{l}\text { Credit Standards Eased } \\
\text { in early } 2000 \text { s Before } \\
\text { the Recent Crisis? }\end{array}$ & $\begin{array}{l}\text { Recent House } \\
\text { Prices }\end{array}$ & $\begin{array}{l}\text { Recent } \\
\text { Construction } \\
\text { Cycle }\end{array}$ \\
\hline Japan & Low & Weak & None reported & Drifting down & Muted \\
\hline Germany & Medium & Weak & $\begin{array}{l}\text { Not much, Girouard et } \\
\text { al., } 2006\end{array}$ & Drifting down & Stable \\
\hline Italy & Low & Semi-strong cycle & None reported & Rose in boom & Muted \\
\hline France & Low & Semi-strong cycle & $\begin{array}{l}\text { Some, Girouard et al., } \\
2006\end{array}$ & Rose in boom & Muted \\
\hline Ireland & Medium & $\begin{array}{l}\text { Strong } \\
\text { boom-bust }\end{array}$ & $\begin{array}{l}\text { Some, Girouard et al., } \\
2006 \text {, reports }\end{array}$ & $\begin{array}{l}\text { Jumped in boom } \\
\text { falling in bust }\end{array}$ & Large Boom-Bust \\
\hline Australia & Low & $\begin{array}{l}\text { Strong } \\
\text { boom-bust }\end{array}$ & $\begin{array}{l}\text { Yes, Williams, 2009, } \\
\text { Girouard et al., } 2006\end{array}$ & $\begin{array}{l}\text { Jumped in boom } \\
\text { falling in bust }\end{array}$ & Semi-strong cycle \\
\hline Spain & Medium & $\begin{array}{l}\text { Strong } \\
\text { boom-bust }\end{array}$ & $\begin{array}{l}\text { Implicit: use of high } \\
\text { home appraisals }\end{array}$ & $\begin{array}{l}\text { Jumped in boom } \\
\text { falling in bust }\end{array}$ & Large Boom-Bust \\
\hline USA & Medium/high & $\begin{array}{l}\text { Strong } \\
\text { boom-bust }\end{array}$ & $\begin{array}{l}\text { Eased much (Duca, et } \\
\text { al., 2009a) }\end{array}$ & $\begin{array}{l}\text { Rose in boom, } \\
\text { Falling in bust }\end{array}$ & Large Boom-Bust \\
\hline UK & Low & $\begin{array}{l}\text { Strong } \\
\text { boom-bust }\end{array}$ & $\begin{array}{l}\text { Some, Girouard, et al., } \\
2006 \text {, reports }\end{array}$ & $\begin{array}{l}\text { Jumped in boom } \\
\text { Falling in bust }\end{array}$ & $\begin{array}{l}\text { Muted, now } \\
\text { falling }\end{array}$ \\
\hline Neth. & Low & $\begin{array}{l}\text { Strong } \\
\text { boom-bust }\end{array}$ & $\begin{array}{l}\text { Some, Girouard, et al., } \\
2006\end{array}$ & $\begin{array}{l}\text { Rose in boom, } \\
\text { Falling in bust }\end{array}$ & Muted \\
\hline
\end{tabular}

1. Housing supply elasticity estimates column entries based on Barker (2003, 2004), DiPasquale (1999), Fortune and Moohan (2008), Malpezzi and MacLennan (2001), Murphy (2006), and Vermeulen and Rowendal (2007).

Table 2: Marginal Propensities to Consume out of Wealth

\begin{tabular}{|c|c|c|c|c|}
\hline Country & Qualitative & Size in aggregate time series & MEW $?^{1}$ & Easing before crisis? \\
\hline France & Low & Insignificant, Catte, et al., 2004 & No & None reported \\
\hline Germany & Low & Insignificant, Catte, et al., 2004 & No & None reported \\
\hline Italy & Negative/Low & $\begin{array}{l}1 \% \text {, Grant \& Peltonen, } 2005 \\
1 \% \text {, Catte, et al., } 2004\end{array}$ & No & None reported \\
\hline Japan & Negative/Low & $\begin{array}{l}<0, \text { Muellbauer \& Murata, } 2009 \\
\text { Insignificant, Catte, et al., } 2004\end{array}$ & No & $\begin{array}{l}\text { Not since 1980s: Muellbauer \& } \\
\text { Murata (2009) }\end{array}$ \\
\hline Spain & Medium & $\begin{array}{l}3 \%, \text { Bover, } 2007 \\
2 \% \text {, Catte, et al., } 2004\end{array}$ & Limited & $\begin{array}{l}\text { Anecdotal reports via appraisals for } \\
\text { home purchase mortgages }\end{array}$ \\
\hline Ireland & $\begin{array}{l}\text { Anecdotally } \\
\text { high \& rising }\end{array}$ & 9\%, Slacalek, 2009 & Limited & Anecdotal reports \\
\hline Australia & High & $\begin{array}{l}\text { 3\%, Dvornak \& Kohler, } 2003 \\
\text { 7\%, Catte, et al., } 2004 \\
\text { 3\%, Muellbauer \& Williams, } 2009\end{array}$ & Yes & $\begin{array}{l}\text { Williams (2009) \& Girouard et al. } \\
\text { (2006) suggest yes }\end{array}$ \\
\hline USA & $\begin{array}{l}\text { High and rose } \\
\text { in boom }\end{array}$ & $\begin{array}{l}\text { 6\%, Aron, et al., } 2009 \\
5 \% \text {, Catte, et al., } 2004 \\
9 \% \text {, Carroll, al., } 2006 \\
12 \% \text {, Case \& Shiller, } 2008\end{array}$ & Yes & $\begin{array}{l}\text { Yes: Carroll et al (2006); Duca, et al. } \\
\text { (2009b) }\end{array}$ \\
\hline UK & Medium-high & $\begin{array}{l}\text { 3\%, Aron, et al. } 2009 \\
\text { 7\%, Catte, et al., } 2004\end{array}$ & Yes & $\begin{array}{l}\text { Yes, late- 1980s: Miles (1992), } \\
\text { Muellbauer \& Murphy, } 1997\end{array}$ \\
\hline
\end{tabular}

1.MEW column entries based on ECB (2003, pp. 50-51), Bover (2007), Duca, et. al (2009b) and Williams (2009). 


\section{BERR}

\section{Spatial Economics Research Centre (SERC)}

London School of Economics

Houghton Street

London WC2A 2AE

Tel: 02078523565

Fax: 02079556848

Web: www.spatialeconomics.ac.uk

SERC is an independent research centre funded by the Economic and Social Research Council (ESRC), Department for Business, Enterprise and Regulatory Reform (BERR), the Department for Communities and Local Government (CLG) and the Welsh Assembly Government. 